\title{
Microarray analysis identifies a set of CXCR3 and CCR2 ligand chemokines as early IFN $\beta$-responsive genes in peripheral blood lymphocytes in vitro: an implication for IFN $\beta$-related adverse effects in multiple sclerosis
}

\author{
Jun-ichi Satoh*1,2, Yusuke Nanri ${ }^{2}$, Hiroko Tabunoki ${ }^{1}$ and \\ Takashi Yamamura²
}

Address: ${ }^{1}$ Department of Bioinformatics, Meiji Pharmaceutical University, 2-522-1 Noshio, Kiyose, Tokyo 204-8588, Japan and ${ }^{2}$ Department of Immunology, National Institute of Neuroscience, NCNP, 4-1-1 Ogawahigashi, Kodaira, Tokyo 187-8502, Japan

Email: Jun-ichi Satoh* - satoj@ncnp.go.jp; Yusuke Nanri - nanriyu@cc.saga-u.ac.jp; Hiroko Tabunoki - tabunoki@my-pharm.ac.jp;

Takashi Yamamura - yamamura@ncnp.go.jp

* Corresponding author

Published: 19 May 2006

BMC Neurology 2006, 6:18 doi:10.1186/1471-2377-6-18
Received: 20 March 2006

Accepted: 19 May 2006

This article is available from: http://www.biomedcentral.com/I47/-2377/6/18

(c) 2006 Satoh et al; licensee BioMed Central Ltd.

This is an Open Access article distributed under the terms of the Creative Commons Attribution License (http://creativecommons.org/licenses/by/2.0), which permits unrestricted use, distribution, and reproduction in any medium, provided the original work is properly cited.

\begin{abstract}
Background: A substantial proportion of multiple sclerosis (MS) patients discontinue interferonbeta (IFN $\beta$ ) treatment due to various adverse effects, most of which emerge at the early phase after initiation of the treatment and then diminish with time. At present, the molecular mechanism underlying IFN $\beta$-related adverse effects remains largely unknown. The aim of this study is to identify a comprehensive list of early IFN $\beta$-responsive genes (IRGs) in peripheral blood mononuclear cells (PBMC) that may play a key role in induction of adverse effects.
\end{abstract}

Methods: Total RNA of PBMC exposed to $50 \mathrm{ng} / \mathrm{ml}$ recombinant human IFN $\beta$ for 3 to 24 hours in vitro was processed for CDNA microarray analysis, followed by quantitative real-time RT-PCR analysis.

Results: Among I,258 genes on the array, IFN $\beta$ elevated the expression of 107 and 87 genes, while it reduced the expression of 22 and 23 genes at 3 and 24 hours, respectively. Upregulated IRGs were categorized into conventional IFN-response markers, components of IFN-signaling pathways, chemokines, cytokines, growth factors, and their receptors, regulators of apoptosis, DNA damage, and cell cycle, heat shock proteins, and costimulatory and adhesion molecules. IFN $\beta$ markedly upregulated CXCR3 ligand chemokines (SCYBII, SCYBIO and SCYB9) chiefly active on effector T helper type I (ThI) T cells, and CCR2 ligand chemokines (SCYA8 and SCYA2) effective on monocytes, whereas it downregulated CXCR2 ligand chemokines (SCYB2, SCYBI and IL8) primarily active on neutrophils.

Conclusion: IFN $\beta$ immediately induces a burst of gene expression of proinflammatory chemokines in vitro that have potential relevance to IFN $\beta$-related early adverse effects in MS patients in vivo. 


\section{Background}

Multiple sclerosis (MS) is an inflammatory demyelinating disease of the central nervous system (CNS) white matter mediated by an autoimmune process, whose development is triggered by a complex interplay of both genetic and environmental factors [1]. Administration of interferon-gamma (IFN $\gamma$ ) induced acute relapses, along with activation of the systemic immune response [2], suggesting that T-lymphocytes producing proinflammatory $\mathrm{T}$ helper type 1 (Th1) cytokines play a pivotal role in the immunopathogenesis of MS. In contrast, interferon-beta (IFN $\beta$ ) significantly reduces the frequency of clinical exacerbations and delays the progression of disability in relapsing-remitting MS (RRMS), accompanied by a reduction in the number of new brain lesions on MRI $[3,4]$. Furthermore, an early initiation of IFN $\beta$ delays the conversion to clinically definite MS in the patients who experienced a first demyelinating event [5]. Although the precise mechanism underlying therapeutic effects of IFN $\beta$ on MS remains to be fully elucidated, previous studies proposed several possibilities, including the inhibition of Th1 cell development [6], induction of Th2 immune deviation [7], restoration of function of the disrupted bloodbrain barrier [8], and downregulation of IFN $\gamma$-induced expression of class II major histocompatibility complex (MHC) molecules [9].

Although clinical benefits of IFN $\beta$ in MS are meaningful, approximately one-third of the patients receiving IFN $\beta$ therapy suffered from a higher or identical annual relapse rate on treatment [10]. New lesion formation on MRI during the treatment correlates with poor response to IFN $\beta$ [11]. Furthermore, a substantial proportion of the patients discontinued IFN $\beta$ treatment because of various adverse effects, including skin reactions, flu-like symptoms, leukocytopenia, liver dysfunction, depression and amenorrhea [12]. The molecular mechanisms accounting for IFN $\beta$-related adverse effects remain unknown, although most of these emerge at the early phase after initiation of the treatment, and then diminish with time [12]. At present, no biologically relevant markers capable of predicting either therapeutic or detrimental responses of IFN $\beta$ in MS are available [13].

DNA microarray technology is a novel approach that allows us to systematically monitor the expression of a large number of genes. It has given new insights into the complexity of molecular interactions promoting the autoimmune process in MS [14]. IFN $\beta$ induces a complex pattern of gene regulation in peripheral blood mononuclear cells (PBMC) of MS [15]. Recently, we studied the gene expression profile of $\mathrm{CD}^{+} \mathrm{T}$ cells isolated from PBMC of 13 Japanese MS patients before and after treatment with IFN $\beta$ - 1 b by analyzing a custom cDNA microarray containing a set of well-annotated, immunologically relevant genes. IFN $\beta$ upregulates the expression of 7 IFN $\beta$ responsive genes (IRGs) during the treatment [16]. A following study performed on RRMS patients receiving IFN $\beta$-1a supported our observations [17]. More recently, we found that the vast majority of genes expressed in $\mathrm{CD}^{+} \mathrm{T}$ cells differentially between 72 untreated MS patients and 22 healthy controls are categorized into apoptosis regulators [18]. Regarding the gene expression profile of IFN $\beta$ responders in MS, baseline levels of IL12 p35 mRNA are significantly lower in the responders [19]. Downregulation of IL-8 expression in PBMC during IFN $\beta$ treatment distinguishes the responders from nonresponders in RRMS [20]. IFN $\beta$ responders differ from nonresponders in the kinetics of expression of IRGs at 3 and 6 months after starting the treatment [21]. A three-dimensional model of gene triplets detected by RT-PCR analysis predicts IFN $\beta$ response status in RRMS [22]. However, all of previous observations do not clearly illustrate the molecular basis of complex biological effects of IFN $\beta$ in MS. Furthermore, no databases of immediate early IRGs in PBMC are currently available.

The present study is designed to identify a comprehensive list of immediate early IRGs in PBMC with potential relevance to IFN $\beta$-related early adverse effects in MS.

\section{Methods}

\section{Treatment of peripheral blood lymphocytes with IFN $\beta$}

PBMC were isolated from heparinized blood by centrifugation on a Ficoll density gradient. PBMC were suspended at $5 \times 10^{6}$ cells $/ \mathrm{ml}$ in RPMI 1640 medium containing $10 \%$ fetal bovine serum, $2 \mathrm{mM}$ L-glutamine, $55 \mu \mathrm{M}$ 2-mercaptoethanol, $100 \mathrm{U} / \mathrm{ml}$ penicillin, and $100 \mu \mathrm{g} / \mathrm{ml}$ streptomycin (culture medium). The cells were incubated in a $5 \% \mathrm{CO}_{2} / 95 \%$ air incubator at $37^{\circ} \mathrm{C}$ for 3 hours to characterize the immediate response or for 24 hours to detect the early response, in the culture medium with or without inclusion of $50 \mathrm{ng} / \mathrm{ml}$ recombinant human IFN $\beta$ (a specific activity of $=2 \times 10^{7}$ units $/ \mathrm{mg}$, PeproTech, London, UK), $50 \mathrm{ng} / \mathrm{ml}$ recombinant human IFN $\gamma$ (a specific activity of $=2 \times 10^{7}$ units $/ \mathrm{mg}$, PeproTech), $50 \mathrm{ng} / \mathrm{ml}$ recombinant human TNF $\alpha$ (a specific activity of $=2 \times 10^{7}$ units/ $\mathrm{mg}$, PeproTech), or $50 \mathrm{ng} / \mathrm{ml}$ recombinant human IL-1 $\beta$ (a specific activity of $=1 \times 10^{7} \mathrm{units} / \mathrm{mg}$, PeproTech). They were then processed for RNA preparation as described previously $[16,18,21]$. Written informed consents were obtained from the subjects involved in the present study according to the form approved by the Ethics Committee of National Center of Neurology and Psychiatry (NCNP), Tokyo, Japan. The samples of the subjects \#1, \#2 and \#4 were processed for both microarray and real-time RT-PCR analysis, while those of the subject \#3 were studied only by real-time RT-PCR analysis. 
Table I: Primers utilized for real-time RT-PCR analysis

\begin{tabular}{|c|c|c|c|c|}
\hline Genes & GenBank accession No. & Sense primers & Antisense primers & PCR product (bp) \\
\hline $\begin{array}{l}\text { ISGI5 } \\
\text { (GIP2) }\end{array}$ & $\frac{N M 005101}{(M \mid 3755)}$ & 5'aagcccctgagcaccgtgttcat3' & 5'ttgatcctgctcggatgctggtg3' & 102 \\
\hline $\begin{array}{l}\text { SCYBIO } \\
\text { (CXCLIO, IP-I0) }\end{array}$ & $\frac{N M 001565}{(X 02530)}$ & $5^{\prime}$ tcgatgcagtgcttccaaggatgg $3^{\prime}$ & 5'ccttcctacaggagtagtagcagc3' & 162 \\
\hline $\begin{array}{l}\text { SCYA8 } \\
\text { (CCL8, MCP2) }\end{array}$ & $\frac{N M 005623}{(Y 10802)}$ & 5'tctgtgctgaccccaaggagagat $3^{\prime}$ & 5'taatgtcacactgcacctggggga3' & 164 \\
\hline $\begin{array}{l}\text { SCYA2 } \\
\text { (CCL2, MCPI) }\end{array}$ & $\frac{N M 002982}{(S 7|5| 3)}$ & $5^{\prime}$ ctagctttccccagacaccctgtt $3^{\prime}$ & 5'ccaggggtagaactgtggttcaag3' & 197 \\
\hline $\begin{array}{l}\text { SCYB2 } \\
\text { (CXCL2, GRO2) }\end{array}$ & NM 002089 & 5'cccgcatcgcccatggttaagaaa 3' & 5'tcttctgttcctgtaaggcagggc $3^{\prime}$ & $|3|$ \\
\hline FOS & NM 005252 & 5'gagctggtgcattacagagaggag3' & 5'ggacttgagtccacacatggatgc $3^{\prime}$ & 140 \\
\hline RGSI4 & $\overline{N M 006480}$ & 5 'tgacagctacccaacagtccagga3' & 5'agggattgggggtgagcttgttga 3 ' & 222 \\
\hline G3PDH & NM 002046 & 5'ccatgttcgtcatgggtgtgaacca3' & 5'gccagtagaggcagggatgatgttc 3 ' & 251 \\
\hline
\end{tabular}

Abbreviations: ISGI5, interferon-stimulated gene 15; SCYBI0, small inducible cytokine subfamily B, member 10; SCYA8, small inducible cytokine subfamily A, member 8; SCYA2, small inducible cytokine subfamily A, member 2; SCYB2, small inducible cytokine subfamily B, member 2; FOS, cellular oncogene c-fos; RGSI4, regulator of G-protein signaling 14; and G3PDH, glyceraldehyde-3-phosphate dehydrogenase

\section{Quantitative real-time RT-PCR analysis}

DNase-treated total RNA was processed for cDNA synthesis using oligo $(\mathrm{dT})_{12-18}$ primers and SuperScript II reverse transcriptase (Invitrogen, Carlsbad, CA). cDNA was amplified by PCR in LightCycler ST300 (Roche Diagnostics, Tokyo, Japan) using SYBR Green I dye and the primer sets listed in Table 1. To calibrate the concentration of mRNA levels in test cDNA samples, serially-diluted purified PCR products generated by conventional RT-PCR (a 10 -fold dilution from $1 \mathrm{pg} / \mathrm{ml}$ to $0.0001 \mathrm{pg} / \mathrm{ml}$ ) were amplified in parallel. The levels of expression of target genes were standardized against those of the glyceraldehyde-3-phosphate dehydrogenase (G3PDH) gene detected in the identical cDNA samples. The assays were performed in triplicate measurements of the same sample and the results were expressed as the average with standard error.

\section{cDNA microarray analysis}

The present study utilized a custom microarray containing duplicate spots of 1,258 cDNA immobilized on a poly-Llysine-coated slide glass (Hitachi Life Science, Kawagoe, Saitama, Japan) $[16,18,21]$. They were prepared by PCR of well-annotated genes, selected from cytokines, growth factors and their receptors, apoptosis regulators, oncogenes, transcription factors, cell cycle regulators and housekeeping genes. The complete gene list is shown in Additional file 1 . Five $\mu \mathrm{g}$ of purified RNA was in vitro amplified and antisense RNA (aRNA) was processed for microarray analysis. aRNA derived from IFN $\beta$-treated PBMC was labeled with a fluorescent dye Cy5, while aRNA of untreated PBMC was labeled with $\mathrm{Cy} 3$ by reverse transcriptase reaction. The arrays were hybridized at $62^{\circ} \mathrm{C}$ for 17 hours in the hybridization buffer containing equal amounts of Cy3- or Cy5-labeled cDNA, and they were then scanned at two different photomultiplier tube (PMT) gains by the
ScanArray 5000 scanner (GSI Lumonics, Boston, MA). The data were analyzed by using the QuantArray software (GSI Lumonics). The fluorescence intensities (FI) of individual spots were quantified following global normalization between Cy3 and Cy5 signals. The average of FI of duplicate spots was calculated, then the ratio of FI of Cy5 signal versus FI of Cy3 signal exceeding 2.0 was defined as significant upregulation, whereas the ratio smaller than 0.5 was considered as substantial downregulation. The impact of inter-experiment variability was validated by analyzing a scatter plot (see Additional file 2).

The IFN-regulated expression of the genes we identified was verified by computerized search of PubMed database and IFN Stimulated Gene (ISG) database [23].

\section{Results \\ Microarray analysis identified immediate early IFN $\beta$ - responsive genes in PBMC}

Among 1,258 genes on the array, IFN $\beta$ treatment for 3 hours elevated the expression of 107 genes in PBMC isolated from a 46 year-old healthy man (the subject \#1), while it reduced the expression of 22 genes (see Additional files 3 and 4 for the complete list). IFN $\beta$ treatment for 24 hours upregulated 87 genes and downregulated 23 genes (see Additional files 5 and 6 for the complete list). Sixty-nine genes were upregulated at both 3 and 24 hours, while only two genes such as FOS and IL1A were downregulated at both. The IRGs upregulated at both time points contained 11 in vivo IRGs reported previously by us [16], including IFIT1 (IFI56), ISG15 (G1P2), IFIT4 (IFI60), IFI27, G1P3 (IFI6-16), IRF7, ABCB2 (TAP1), ATF3, IFITM1 (IFI17), SULT1C1, and TNFAIP6, whose expression was elevated in T cells and non-T cells ex vivo, isolated from 13 RRMS patients during IFN $\beta$ treatment for 3 to 6 months. Top 20 most significant genes, either 
Table 2: Top 20 upregulated genes in PBMC following exposue to IFN $\beta$

\begin{tabular}{|c|c|c|c|c|}
\hline No. & Су5/Cy3 ratio & Symbol & GenBank & Gene name \\
\hline \multicolumn{5}{|c|}{ at 3 hours } \\
\hline I & 188.50 & $\underline{\mathrm{IFITI}}$ & $\underline{\times 03557}$ & interferon-induced protein with tetratricopeptide repeats I (IFI56) \\
\hline 2 & 149.82 & SCYBII & AF0305I4 & chemokine (C-X-C motif) ligand II (CXCLI I, IP-9, I-TAC) \\
\hline 3 & 81.81 & $\underline{|S G| 5}$ & MI3755 & interferon-stimulated gene ISG I5 (GIP2) \\
\hline 4 & 67.84 & $\underline{\text { IFIT4 }}$ & AF083470 & interferon-induced protein with tetratricopeptide repeats 4 (IFI60) \\
\hline 5 & 66.38 & MXI & M30817 & myxovirus resistance protein I (MXA) \\
\hline 6 & 64.43 & SCYBIO & $\underline{\mathrm{X02530}}$ & chemokine (C-X-C motif) ligand 10 (CXCLIO, IP-I0) \\
\hline 7 & 55.01 & SCYA8 & $\underline{Y 10802}$ & chemokine (C-C motif) ligand 8 (CCL8, MCP2) \\
\hline 8 & 36.88 & SCYB9 & $\underline{\times 72755}$ & chemokine (C-X-C motif) ligand 9 (CXCL9, MIG) \\
\hline 9 & 35.14 & TNFSFIO & $\underline{\mathrm{U} 37518}$ & tumor necrosis factor superfamily, member 10 (TRAIL) \\
\hline 10 & 32.86 & $M \times 2$ & M30818 & myxovirus resistance protein 2 (MXB) \\
\hline 11 & 21.99 & $\underline{I F I 27}$ & $\times 67325$ & interferon alpha-inducible protein 27 \\
\hline 12 & 21.98 & GIP3 & X02492 & interferon alpha-inducible protein (IFI6-16), isoform a \\
\hline 13 & 19.26 & ISG20 & $\underline{\mathrm{U} 88964}$ & interferon-stimulated gene ISG 20 \\
\hline 14 & 19.12 & STATI & M97935 & signal transducer and activator of transcription I, isoform alpha \\
\hline 15 & |3.7| & $\underline{\text { IRF7 }}$ & $\underline{\mathrm{U}} 33830$ & interferon-regulatory factor 7 , isoform alpha \\
\hline 16 & 13.44 & $\overline{\text { CCNAI }}$ & $\underline{\mathrm{U} 66838}$ & cyclin Al \\
\hline 17 & 12.72 & IL6 & $\overline{M I 4584}$ & interleukin 6 \\
\hline 18 & 10.86 & ILIRN & $\underline{\times 53296}$ & interleukin I receptor antagonist, isoform I \\
\hline 19 & 10.47 & SCYA2 & $\underline{S 71513}$ & chemokine (C-C motif) ligand 2 (CCL2, MCPI) \\
\hline 20 & 9.91 & STAT2 & M97934 & signal transducer and activator of transcription 2 \\
\hline \multicolumn{5}{|c|}{ at 24 hours } \\
\hline I & 193.19 & SCYA8 & $\underline{Y 10802}$ & chemokine (C-C motif) ligand 8 (CCL8, MCP2) \\
\hline 2 & 124.77 & IFITI & $\underline{\mathrm{X} 03557}$ & interferon-induced protein with tetratricopeptide repeats I (IFI56) \\
\hline 3 & 107.21 & $\underline{\mathrm{IFI} 27}$ & $\underline{\mathrm{X} 67325}$ & interferon alpha-inducible protein 27 \\
\hline 4 & 70.51 & $\underline{\text { ISG I } 5}$ & M13755 & interferon-stimulated gene ISG I5 (GIP2) \\
\hline 5 & 53.22 & SCYBII & $\mathrm{AF} 030514$ & chemokine (C-X-C motif) ligand II (CXCLI I, IP-9, I-TAC) \\
\hline 6 & 38.07 & $\mathrm{MXI}$ & M30817 & myxovirus resistance protein I (MXA) \\
\hline 7 & 37.95 & $\underline{\text { IFIT4 }}$ & AF083470 & interferon-induced protein with tetratricopeptide repeats 4 (IFI60) \\
\hline 8 & 31.56 & SCYBIO & $\underline{X 02530}$ & chemokine (C-X-C motif) ligand I0 (CXCLI0, IP-I0) \\
\hline 9 & 23.65 & $\underline{\mathrm{GIP} 3}$ & $\underline{\mathrm{X02492}}$ & interferon alpha-inducible protein (IFI6-16), isoform a \\
\hline 10 & 23.10 & $\overline{\text { TNFSFIO }}$ & U37518 & tumor necrosis factor superfamily, member 10 (TRAIL) \\
\hline 11 & 21.31 & $M \times 2$ & M30818 & myxovirus resistance protein 2 (MXB) \\
\hline 12 & 20.68 & PDGFRL & $\overline{\mathrm{D} 37965}$ & platelet-derived growth factor receptor-like protein \\
\hline 13 & 15.95 & CD80 & M27533 & CD80 antigen (B7-I) \\
\hline 14 & 13.99 & $\underline{\text { IRF7 }}$ & $\underline{\mathrm{U} 53830}$ & interferon-regulatory factor 7 , isoform alpha \\
\hline 15 & 13.93 & $\overline{\text { ILIRN }}$ & $\times 53296$ & interleukin I receptor antagonist, isoform I \\
\hline 16 & 13.31 & ISG20 & $\underline{\mathrm{U} 88964}$ & interferon-stimulated gene ISG20 \\
\hline 17 & 11.81 & IFITMI & $\overline{04164}$ & interferon induced transmembrane protein I (IFII7) \\
\hline 18 & 8.67 & SCYA2 & $\underline{\mathrm{S} 1513}$ & chemokine (C-C motif) ligand 2 (CCL2, MCPI) \\
\hline 19 & 8.54 & IL6 & $\underline{M 14584}$ & interleukin 6 \\
\hline 20 & 8.51 & IL8RB & $\underline{\mathrm{L} 19593}$ & interleukin 8 receptor beta (CXCR2) \\
\hline
\end{tabular}

Top 20 upregulated genes in PBMC of the subject \#I (a 46 year-old healthy man) by exposure to $50 \mathrm{ng} / \mathrm{ml}$ recombinant human IFN $\beta$ for 3 or 24 hours are listed with Cy5/Cy3 signal intensity ratio, gene symbol, GenBank accession number, and gene name. In vivo IRGs in T cells and non-T cells of RRMS patients reported previously (Ref. 16) are underlined.

upregulated or downregulated, are listed in Table 2 and Table 3, respectively. All of top 20 upregulated genes were found as known IRGs identified in various cell types by searching through PubMed and ISG databases.

The upregulated IRGs in the complete lists (see Additional files 3 and 5) were classified into several functional categories following; (i) conventional IFN-response markers $(\mathrm{n}=12)$, (ii) components of classical and Toll-like receptor (TLR)-dependent IFN-signaling pathways $(n=12)$, (iii) chemokines and their receptors ( $\mathrm{n}=11)$, (iv) cytokines, growth factors and their receptors $(\mathrm{n}=17)$, ( $\mathrm{v})$ apoptosis, DNA damage, and cell cycle regulators ( $\mathrm{n}=$ 29), (vi) heat shock proteins ( $\mathrm{n}=9$ ), and (vii) costimulatory and adhesion molecules $(\mathrm{n}=7)$ (Table 4$)$. The chemokine and chemokine receptor group included both CXC and CC chemokines and their receptors, such as SCYB11 (CXCL11, I-TAC), SCYB10 (CXCL10, IP-10), SCYA8 (CCL8, MCP2), SCYB9 (CXCL9, MIG), SCYA2 (CCL2, MCP1), CCR5, SCYA4 (CCL4, MIP1B), IL8RB (CXCR2), 
Table 3: Top 20 downregulated genes in PBMC following exposue to IFN $\beta$

\begin{tabular}{|c|c|c|c|c|}
\hline No. & Сy5/Cy3 ratio & Symbol & GenBank & Gene name \\
\hline \multicolumn{5}{|c|}{ at 3 hours } \\
\hline I & 0.29 & RGSI4 & NM 006480 & regulator of G-protein signaling 14 \\
\hline 2 & 0.30 & FOS & NM 005252 & cellular oncogene c-fos \\
\hline 3 & 0.31 & SCYB2 & NM 002089 & chemokine (C-X-C motif) ligand 2 (GRO2, MIP2A) \\
\hline 4 & 0.41 & PPARG2 & $\underline{\mathrm{U} 63415}$ & peroxisome proliferative activated receptor gamma, isoform 2 \\
\hline 5 & 0.41 & TNFSFII & NM 003701 & tumor necrosis factor ligand superfamily, member II (RANKL), isoform I \\
\hline 6 & 0.42 & $\mathrm{ABCC} 4$ & NM 005845 & ATP-binding cassette, subfamily C, member 4 (MRP4) \\
\hline 7 & 0.42 & MERTK & NM 006343 & c-mer proto-oncogene tyrosine kinase \\
\hline 8 & 0.42 & TGFBR3 & NM 003243 & transforming growth factor beta receptor III (betaglycan) \\
\hline 9 & 0.44 & ATP2BI & 04027 & ATPase, $\mathrm{Ca}++$ transporting, plasma membrane $\mathrm{I}$, isoform Ib \\
\hline 10 & 0.45 & SCYBI & NM 001511 & chemokine (C-X-C motif) ligand I (GROI, MGSA) \\
\hline 11 & 0.45 & IL8 & NM 000584 & interleukin 8 (SCYB8, CXCL8) \\
\hline 12 & 0.45 & TRAF5 & NM 004619 & TNF receptor-associated factor 5 , variant I \\
\hline 13 & 0.47 & CD3G & NM 000073 & CD3G antigen, gamma polypeptide \\
\hline 14 & 0.47 & ILIA & NM 000575 & interleukin I alpha \\
\hline 15 & 0.47 & TCFL5 & NM 006602 & transcription factor-like 5 \\
\hline 16 & 0.48 & LAT & AF036905 & linker for activation of $\mathrm{T}$ cells, isoform $\mathrm{b}$ \\
\hline 17 & 0.48 & HNMT & U08092 & histamine N-methyltransferase, isoform I \\
\hline 18 & 0.48 & SLC3AI & NM 00034I & solute carrier family 3 , member I \\
\hline 19 & 0.49 & MGSTI & NM 145764 & microsomal glutathione S-transferase I, variant Id \\
\hline 20 & 0.49 & TNFSF8 & NM 001244 & tumor necrosis factor ligand superfamily, member 8 (CD30L) \\
\hline \multicolumn{5}{|c|}{ at 24 hours } \\
\hline 1 & 0.18 & $\mathrm{ABCC} 3$ & AF083552 & ATP-binding cassette, subfamily $C$, member 3 , isoform MRP3 \\
\hline 2 & 0.20 & FOS & NM 005252 & cellular oncogene c-fos \\
\hline 3 & 0.30 & ALDH2 & NM 000690 & aldehyde dehydrogenase 2 family \\
\hline 4 & 0.30 & TPSTI & NM 003596 & tyrosylprotein sulfotransferase I \\
\hline 5 & 0.31 & CD9 & $\overline{N M 001769}$ & CD9 antigen \\
\hline 6 & 0.34 & NRGI & NM 013962 & neuregulin I, isoform GGF2 \\
\hline 7 & 0.35 & TLR5 & NM 003268 & toll-like receptor 5 \\
\hline 8 & 0.36 & PTGSI & NM 000962 & prostaglandin-endoperoxide synthase I (COXI), isoform I \\
\hline 9 & 0.37 & MGST2 & NM 002413 & microsomal glutathione S-transferase 2 \\
\hline 10 & 0.38 & ITGAM & NM 000632 & integrin, alpha $M(C D \mid I B, M A C-I, C R 3 A)$ \\
\hline 11 & 0.38 & SCYA24 & NM 002991 & chemokine (C-C motif) ligand 24 (eotaxin 2) \\
\hline 12 & 0.38 & CYP27AI & NM 000784 & cytochrome $\mathrm{P} 450$, family 27 , subfamily A, polypeptide I (CTX) \\
\hline 13 & 0.39 & ALDHIAI & NM 000689 & aldehyde dehydrogenase I family, member AI \\
\hline 14 & 0.39 & MYCLI & NM 005376 & v-myc myelocytomatosis viral oncogene homolog I (LMYC) \\
\hline 15 & 0.41 & ATP6AP2 & NM 005765 & ATPase, $\mathrm{H}+$ transporting, lysosomal accessory protein 2 (ATP6M8-9) \\
\hline 16 & 0.44 & PRKCG & NM 002739 & protein kinase $C$ gamma \\
\hline 17 & 0.45 & ATP2BI & 04027 & ATPase, $\mathrm{Ca}^{++}$transporting, plasma membrane $\mathrm{I}$, isoform Ib \\
\hline 18 & 0.46 & APIS2 & NM 003916 & adaptor-related protein complex I, sigma 2 subunit \\
\hline 19 & 0.47 & NR6AI & $\overline{N M 001489}$ & nuclear receptor subfamily 6 , group A, member I (RTR), isoform 2 \\
\hline 20 & 0.47 & GCG & $\overline{N M \quad 173916}$ & glucagon \\
\hline
\end{tabular}

Top 20 downregulated genes in PBMC of the subject \#I (a 46 year-old healthy man) by exposure to $50 \mathrm{ng} / \mathrm{ml}$ recombinant human IFN $\beta$ for 3 or 24 hours are listed with Cy5/Cy3 signal intensity ratio, gene symbol, GenBank accession number, and gene name.

SCYA3 (CCL3, MIP1A), SCYA19 (CCL19, MIP3B) and SCYA13 (CCL13, MCP4). It is worthy to note that both CXCR3 ligand chemokines (SCYB11, SCYB10 and SCYB9) and CCR2 ligand chemokines (SCYA10 and SCYA2) were clustered in top 20 genes greatly elevated at 3 and 24 hours of IFN $\beta$ treatment (Table 2). With respect to top 20 downregulated genes, four genes such as SCYB2 (CXCL2, GRO2), SCYB1 (CXCL1, GRO1), IL8 (SCYB8, CXCL8), and SCYA24 (eotaxin-2) were categorized into the chemokine group (Table 3). Among them, SCYB2, SCYB1 and IL8, whose expression was reduced immedi- ately at 3 hours of IFN $\beta$ treatment, belong to CXCR2 ligand chemokines. Although the analysis in the present study was a single microarray for each sample design, the results from two additional subjects, including a 28 yearold healthy man (the subject \#2) and a 27 year-old woman with RRMS who was a dropout of IFN $\beta$ treatment due to induction of frequent severe relapses (the subject \#4), verified the observations of immediate early induction of CXCR3 ligand and CCR2 ligand chemokine genes in PBMC by exposure to IFN $\beta$, supporting the reproducibility of these results (see Additional file 7). 
Table 4: Functional classification of IFN $\beta$-upregulated genes in PBMC

\begin{tabular}{|c|c|c|c|}
\hline \multicolumn{2}{|c|}{ Categories } & \multirow{2}{*}{$\begin{array}{l}\text { Number } \\
\text { of genes }\end{array}$} & \multirow{2}{*}{$\begin{array}{l}\text { Gene symbols (alternative symbols or names) } \\
\text { IFITI (IFI56), ISGI5 (GIP2), IFIT4 (IFI60), MXI (MXA), MX2 (MXB), } \\
\text { IFI27, GIP3 (IFI6- I6), ISG20, IFII6, IFITMI (IFII7), IFITM3 (I-8U), } \\
\text { ABCB2 (TAPI) }\end{array}$} \\
\hline $\mathbf{I}$ & Conventional IFN-response markers & & \\
\hline 2 & Components of IFN-signaling pathways & 12 & $\begin{array}{l}\text { STATI, IRF7, STAT2, JAK2, IRF2, ISGF3G (IRF9), MYD88, IRF8, } \\
\text { STAT3, JAK3, IRFI, TLR3 }\end{array}$ \\
\hline 3 & Chemokines and receptors & 11 & $\begin{array}{l}\text { SCYBII (CXCLII, I-TAC), SCYBI0 (CXCLI0, IP-I0), SCYA8 (CCL8, } \\
\text { MCP2), SCYB9 (CXCL9, MIG), SCYA2 (CCL2, MCPI), CCR5, SCYA4 } \\
\text { (CCL4, MIPIB), IL8RB (CXCR2), SCYA (CCL3, MIPIA), SCYAI9 } \\
\text { (CCLI9, MIP3B), SCYAI3 (CCLI3, MCP4) }\end{array}$ \\
\hline 4 & Cytokines, growth factors, and receptors & 17 & $\begin{array}{l}\text { IL6, ILRN (IL-I receptor antagonist), ILIR2, ILI5RA, ILI 5, SPPI } \\
\text { (osteopontin), CSFI, ILI 2RB2, TNF (TNFA), IL2RB, IFNG, NTRKI } \\
\text { (TRKA), PDGFRL, TNFAIP6, KITLG (SCF), ILI I0, IL3RA }\end{array}$ \\
\hline 5 & Apotosis, DNA damage, and cell cycle regulators & 29 & $\begin{array}{l}\text { TNFSFI0 (TRAIL), CASPI0, BAGI, TNFRSF6 (FAS), CASP4, TRADD, } \\
\text { GZMA, CASP7, RIPK2, MAD, RIPKI, CFLAR (FLIP), RELA, STK3, } \\
\text { CASPI, TNFSF6 (FASL), PARP4, TANK (I-TRAF), POLE2, LMNBI, } \\
\text { E2F2, CCNAI (cyclin AI), CDKNIA (p2I), PPPIRI5A (GADD34), } \\
\text { CASP3, CDKNIC (p57), CDK5R2 (p39), TERFI, NBSI (nibrin) }\end{array}$ \\
\hline 6 & Heat shock proteins & 9 & $\begin{array}{l}\text { HSPA6 (HSP70B'), HSJ2 (HSPF4), HSPAIA (HSP70-I), HSPAIB } \\
\text { (HSP70-2), HSPCA (HSP90A), HSPA5 (GRP78), HSPAIL (HSP70- } \\
\text { HOM), HSPA8 (HSC70), HSPBI (HSP27) }\end{array}$ \\
\hline 7 & Costimulatory and adhesion molecules & 7 & $\begin{array}{l}\text { CD80 (B7-I), SELL (selectin L), TNFRSF5 (CD40), CDI63, CD86 (B7. } \\
\text { 2), HLA-DRA, FCERIG }\end{array}$ \\
\hline
\end{tabular}

The upregulated IRGs in PBMC listed in Additional files 3 and 5 were classified into seven functional categories.

\section{Real-time RT-PCR analysis validated IFN $\beta$-regulated expression of IRGs identified by microarray analysis}

Although the microarray we utilized contains total 64 spots of the G3PDH gene (see Additional file 1), G3PDH was neither identified as a significantly upregulated nor a downregulated gene in the microarray analysis, suggesting that G3PDH represents a reliable housekeeping gene in gene expression analysis of PBMC following treatment with IFN $\beta$. Therefore, quantitative real-time RT-PCR analysis was performed by evaluating the levels of expression of target genes standardized against those of G3PDH detected in the identical cDNA samples. It verified the key observations of microarray analysis, such as marked upregulation of ISG15, the prototype of IRGs (Figure 1ac), and great elevation of SCYB10, SCYA8 and SCYA2 (Figures 2, 3, 4a-c) in PBMC at both 3 and 24 hours of IFN $\beta$ treatment. Furthermore, the quantitative analysis confirmed substantial downregulation of FOS at both time points (Figure 5a-c), and RGS14 and SCYB2 predominantly at 3 hours (Figures 6, 7a-c). Exposure of PBMC to IFN $\gamma$ greatly elevated the expression of SCYB10 and SCYA2, and to a lessor extent, ISG15 and SCYA 8 at both time points (Figures 1, 2, 3, 4d), suggesting a functional overlap in induction of CXCR3 ligand and CCR2 ligand chemokines between type I and type II IFN signaling pathways. In contrast, TNF $\alpha$ and IL- $1 \beta$ the prototype of proinflammatory cytokines, did not at all elevate the levels of expression of ISG15, SCYB10 or SCYA8 (Figures 1, 2, 3e, $\mathrm{f}$ ), while IL- $1 \beta$ significantly ( $p=0.041$ at 3 hours and $p=$ 0.004 at 24 hours by two-sided paired t-test) but TNF $\alpha$ only marginally ( $p=0.2102$ at 3 hours and $p=0.0825$ at 24 hours by two-sided paired t-test) upregulated SCYA2 expression (Figure $4 \mathrm{e}, \mathrm{f}$ ). Treatment with IFN $\gamma$, TNF $\alpha$ or IL-1 $\beta$ reduced the levels of FOS and RGS14 substantially at 24 hours (Figures 5, 6d-f). IFN $\gamma$ reduced the expression of SCYB2, whereas TNF $\alpha$ and IL-1 $\beta$ elevated its levels at both time points, suggesting differential regulation of SCYB2 gene expression in PBMC by exposure to distinct cytokines (Figure $7 \mathrm{~d}-\mathrm{f}$ ). The IFN $\beta$-regulated gene expression pattern was similar among PBMC derived from three distinct healthy subjects \#1, \#2 and \#3, supporting the reproducibility of these observations (Figures 1, 2, 3, 4, 5, $6,7 \mathrm{a}-\mathrm{c})$. 
(a)

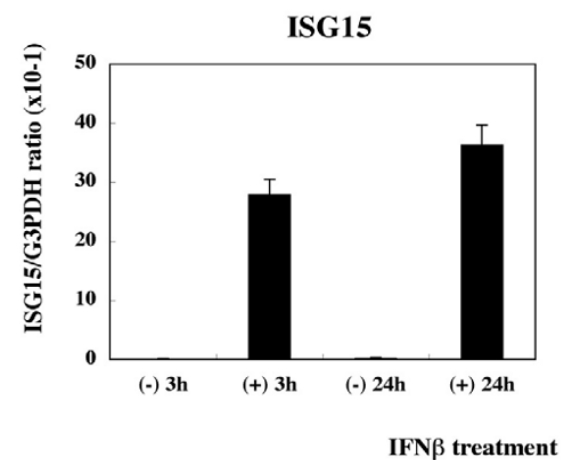

(d)

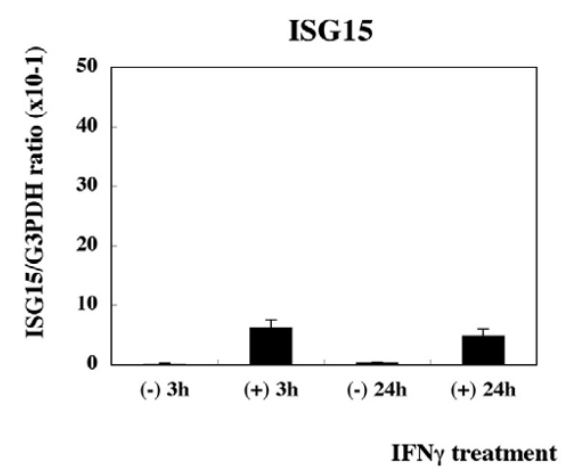

(b)

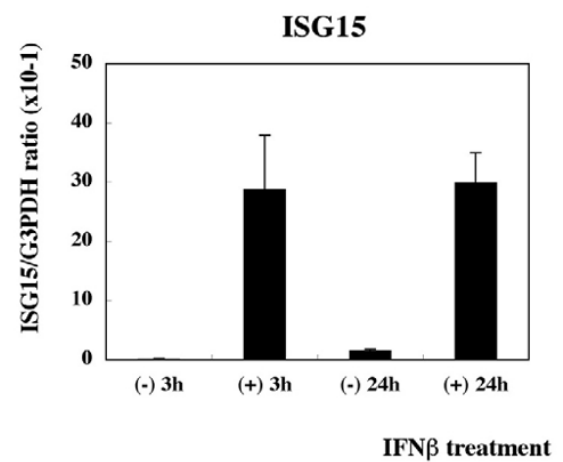

(e)

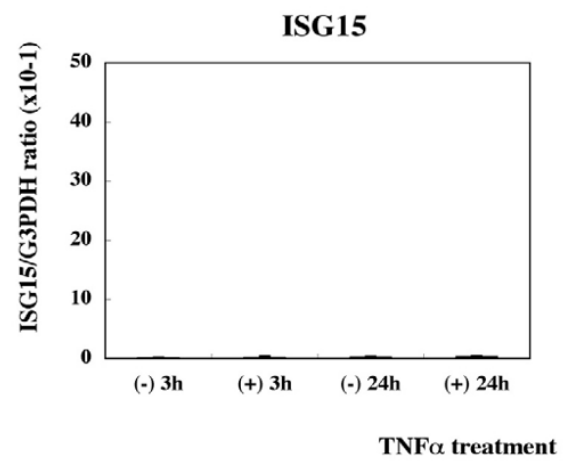

(c)

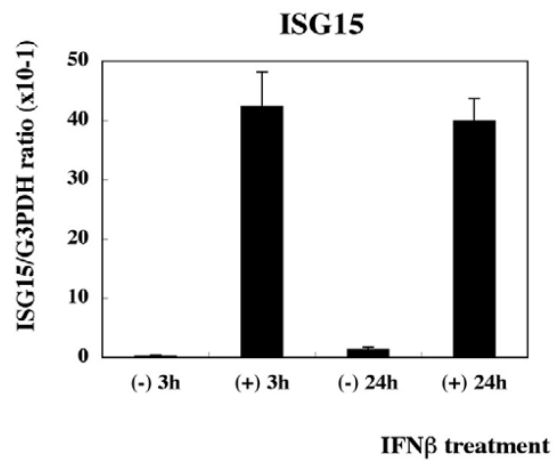

(f)

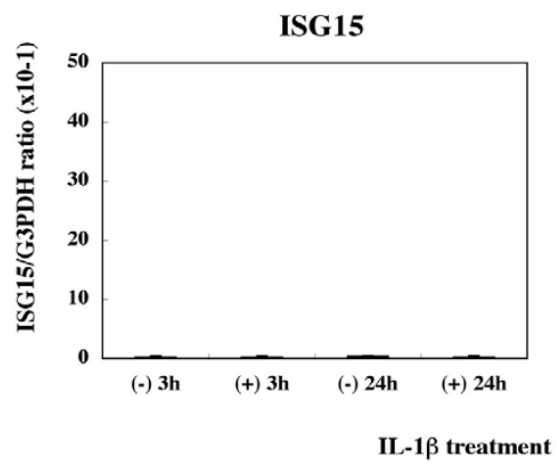

Figure I

Real-time RT-PCR analysis of ISGI5 expression in PBMC. PBMC derived from three distinct healthy subjects numbered \#I (a 46 year-old man), \#2 (a 28 year-old man), and \#3 (a 42 year-old woman) were incubated for 3 hours or 24 hours in the culture medium with (+) or without (-) inclusion of recombinant human IFN $\beta$, IFN $\gamma$, TNF $\alpha$ or IL-I $\beta$ at a concentration of $50 \mathrm{ng} / \mathrm{ml}$ each. cDNA was processed for real-time PCR analysis using specific primers listed in Table I. The levels of expression of ISG I 5 are standardized against those of the glyceraldehyde-3-phosphate dehydrogenase (G3PDH) gene detected in identical cDNA samples. The assays were performed in triplicate measurements of the same sample, and the results were expressed as the average with standard error. The panels represent the expression of ISGI5 in (a) \#I, IFN $\beta$; (b) \#2, IFN $\beta$; (c) \#3, IFN $\beta$; (d) \#I, IFN $\gamma ;$ (e) \#I, TNF $\alpha$; and (f) \#I, IL-I $\beta$. 
(a)

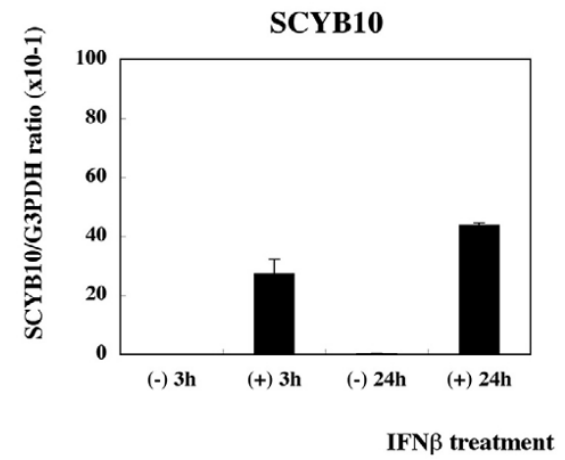

(d)

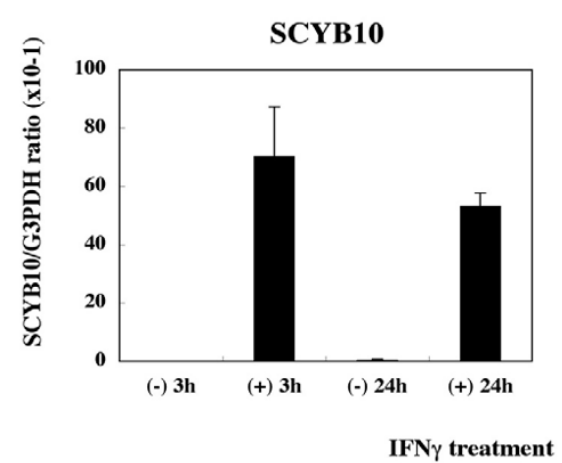

(b)

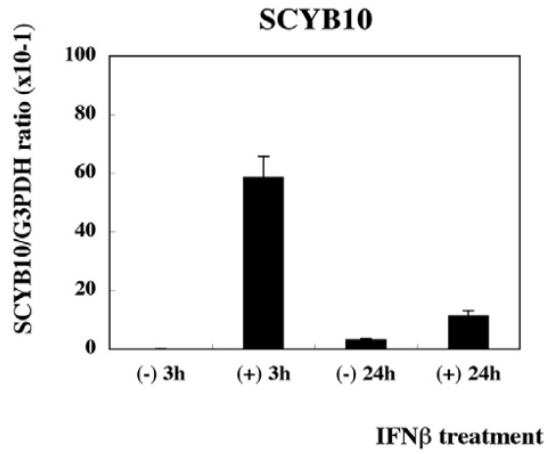

(e)

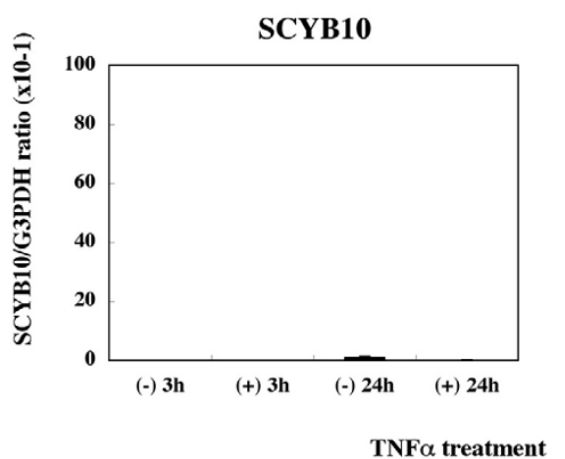

(c)

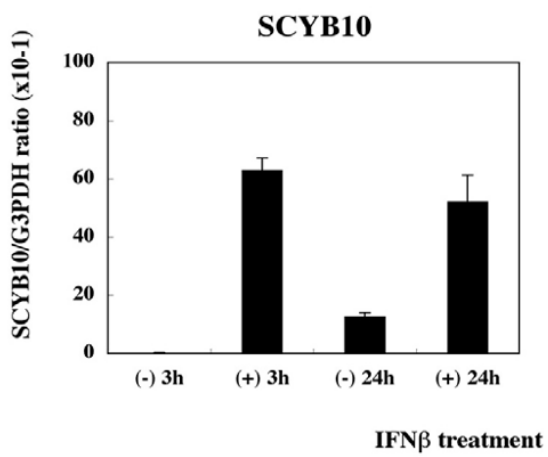

(f)

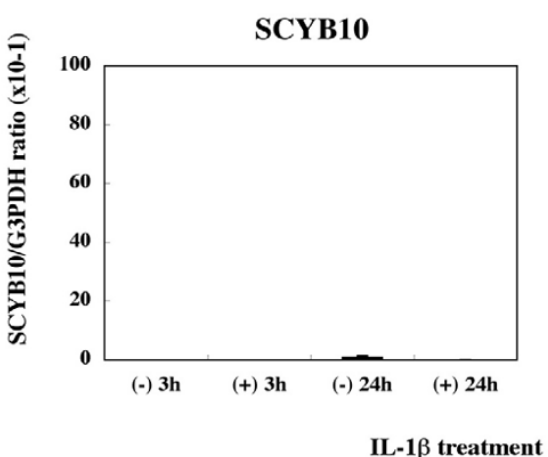

Figure 2

Real-time RT-PCR analysis of SCYBIO expression in PBMC. See the footnote of Figure I. The panels represent the expression of SCYBIO in (a) \#I, IFN $\beta$; (b) \#2, IFN $\beta$; (c) \#3, IFN $\beta$; (d) \#I, IFN $\gamma$; (e) \#I, TNF $\alpha$; and (f) \#I, IL-I $\beta$. 
(a)

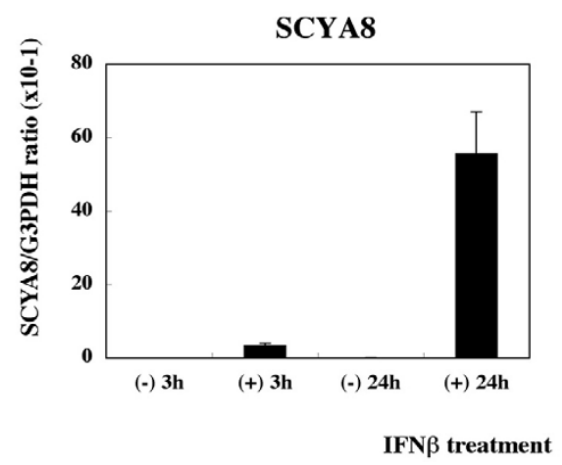

(d)

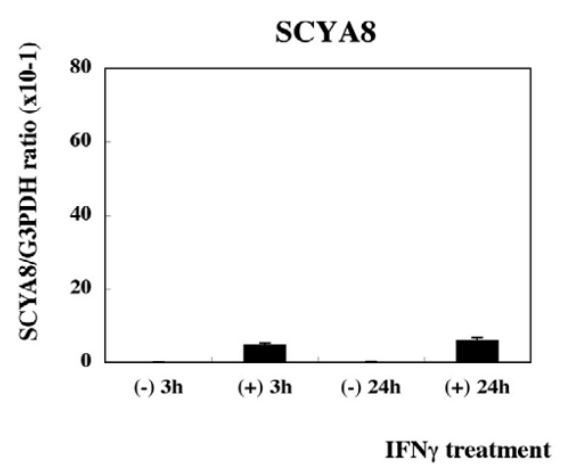

(b)

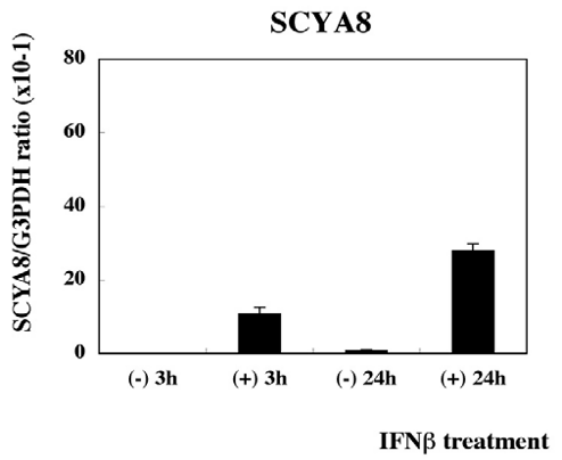

(e)

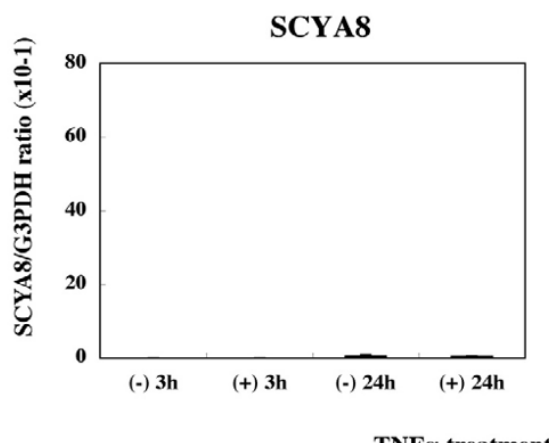

(c)

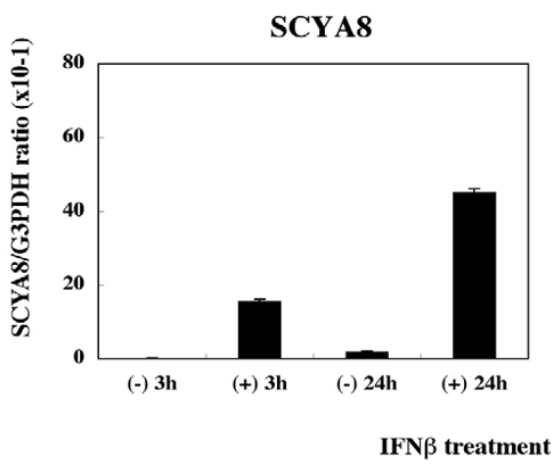

(f)

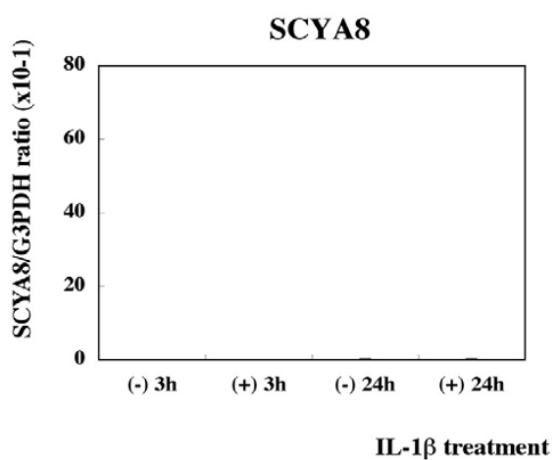

Figure 3

Real-time RT-PCR analysis of SCYA8 expression in PBMC. See the footnote of Figure I. The panels represent the expression of SCYA8 in (a) \#I, IFN $\beta$; (b) \#2, IFN $\beta$; (c) \#3, IFN $\beta$; (d) \#I, IFN $\gamma$; (e) \#I, TNF $\alpha$; and (f) \#I, IL-I $\beta$. 
(a)

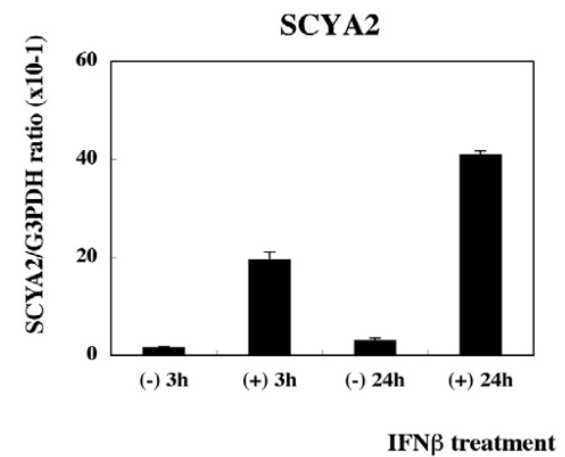

(d)

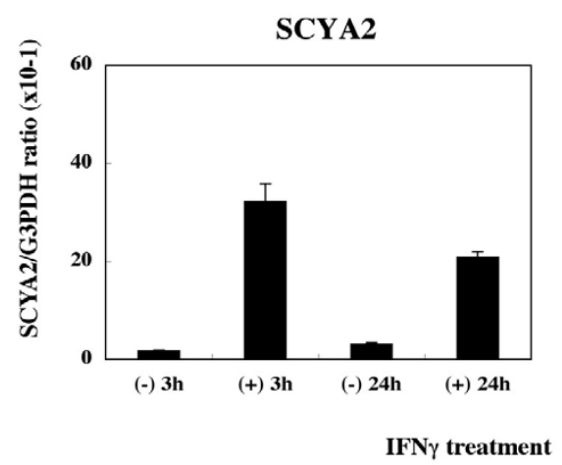

(b)

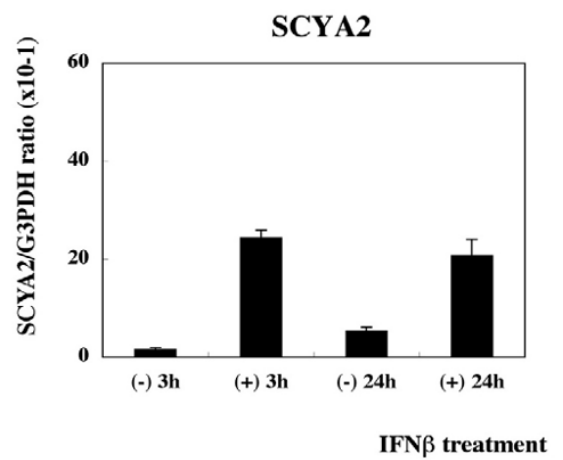

(e)

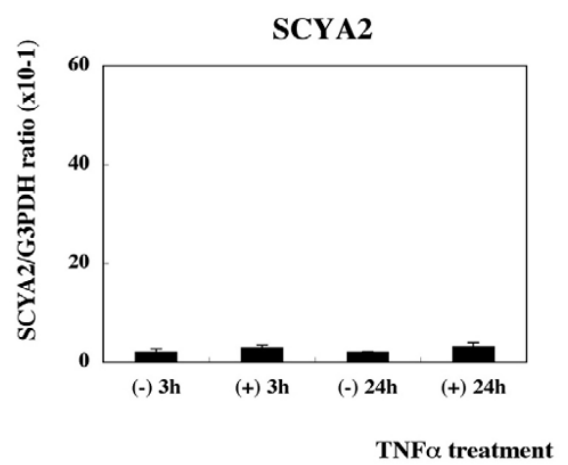

(c)

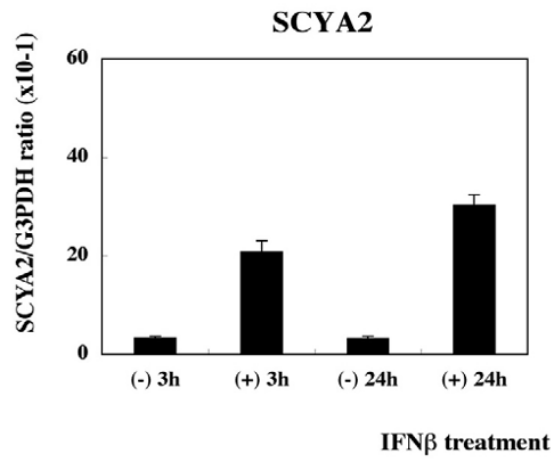

(f)

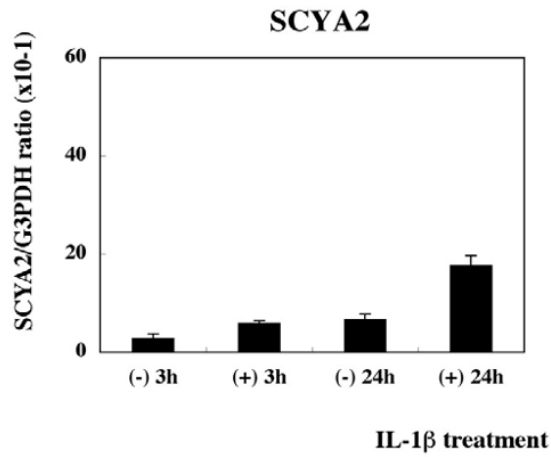

Figure 4

Real-time RT-PCR analysis of SCYA2 expression in PBMC. See the footnote of Figure I. The panels represent the expression of SCYA2 in (a) \#I, IFN $\beta$; (b) \#2, IFN $\beta$; (c) \#3, IFN $\beta$; (d) \#I, IFN $\gamma$; (e) \#I, TNF $\alpha$; and (f) \#I, IL-I $\beta$. 
(a)

FOS

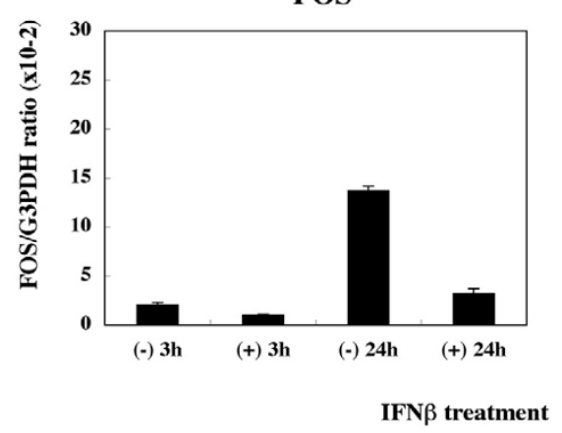

(d)

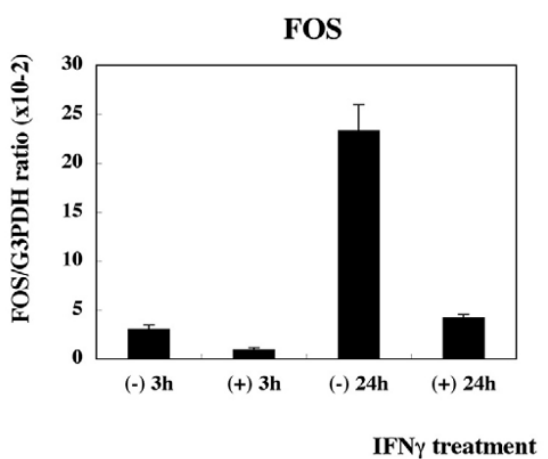

(b)

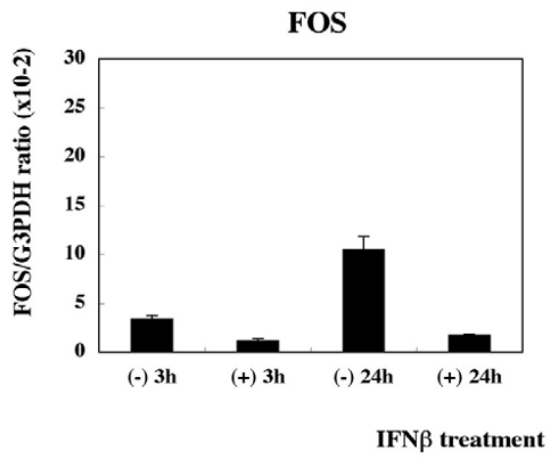

(e)

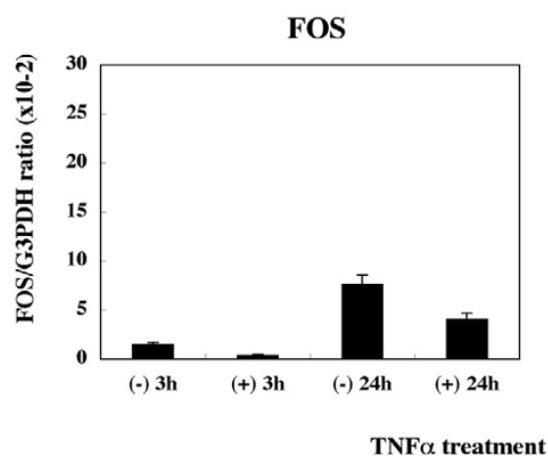

(c)

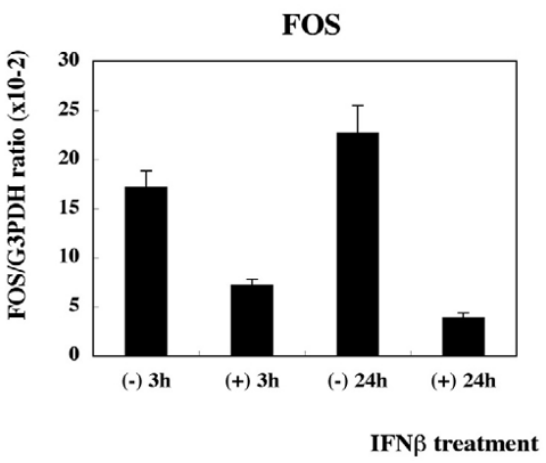

(f)

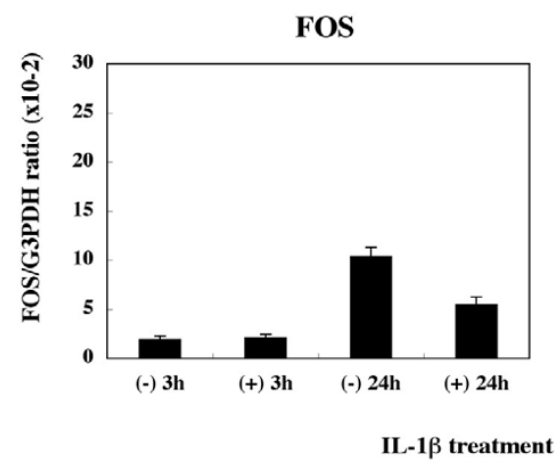

Figure 5

Real-time RT-PCR analysis of FOS expression in PBMC. See the footnote of Figure I. The panels represent the expression of FOS in (a) \#I, IFN $\beta$; (b) \#2, IFN $\beta$; (c) \#3, IFN $\beta$; (d) \#I, IFN $\gamma$; (e) \#I, TNF $\alpha$; and (f) \#I, IL-I $\beta$. 
(a)

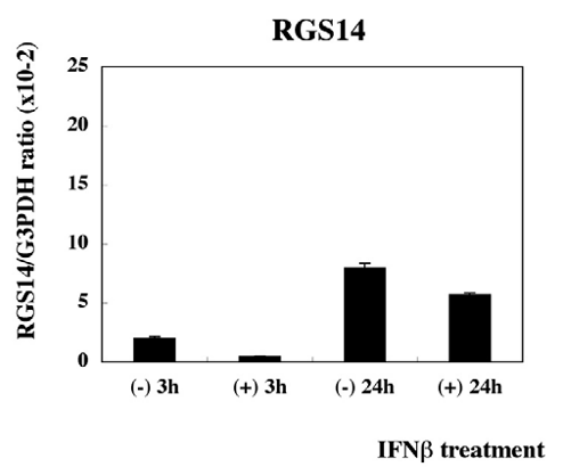

(d)

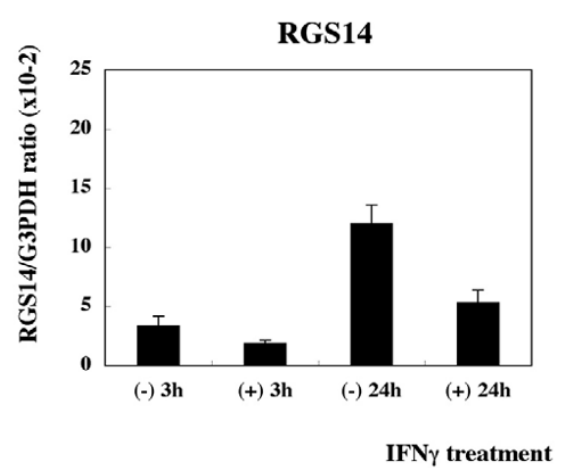

(b)

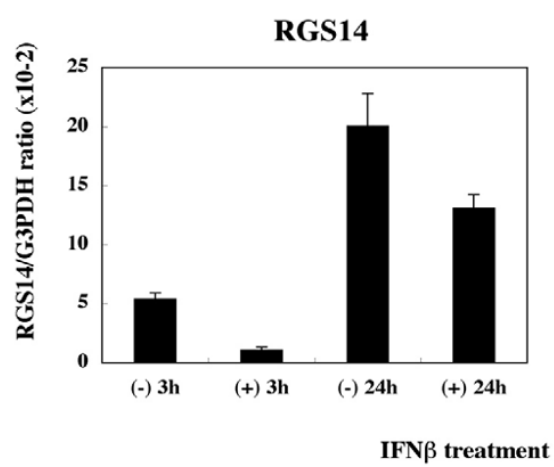

(e)

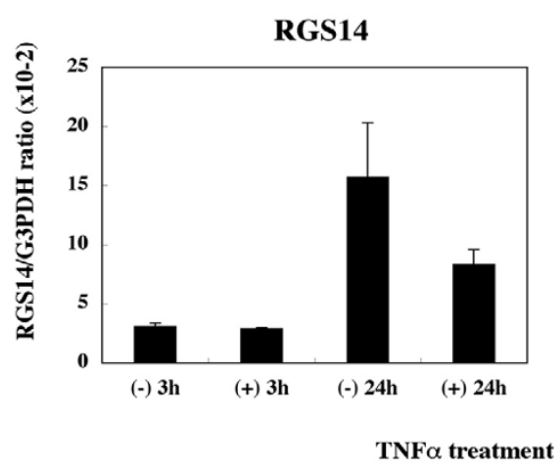

(c)

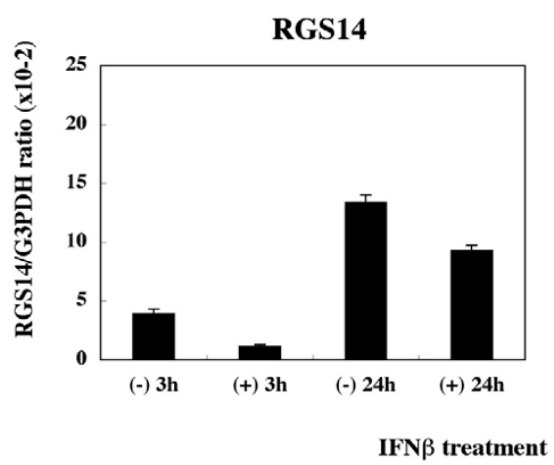

(f)

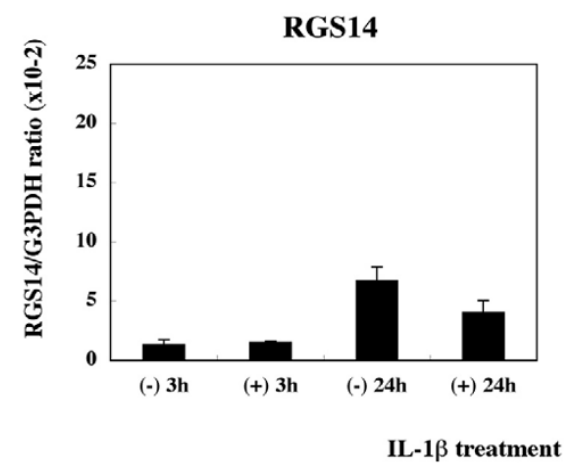

Figure 6

Real-time RT-PCR analysis of RGS I 4 expression in PBMC. See the footnote of Figure I. The panels represent the expression of RGSI4 in (a) \#I, IFN $\beta$; (b) \#2, IFN $\beta$; (c) \#3, IFN $\beta$; (d) \#I, IFN $\gamma$; (e) \#I, TNF $\alpha$; and (f) \#I, IL-I $\beta$. 
(a)

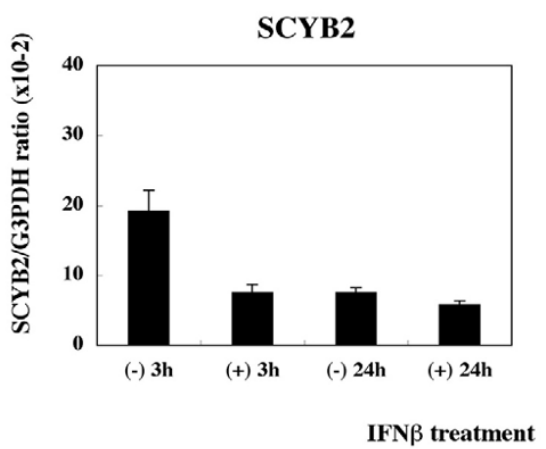

(d)

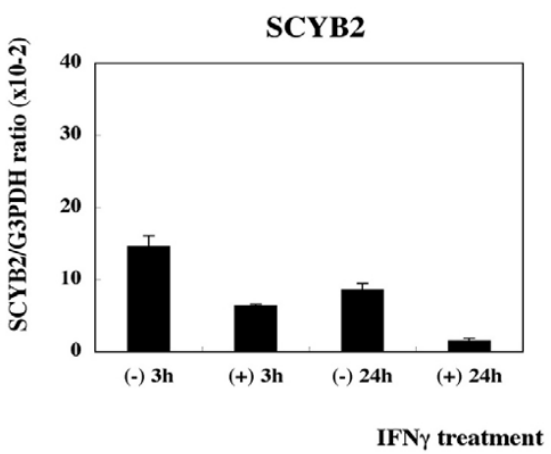

(b)

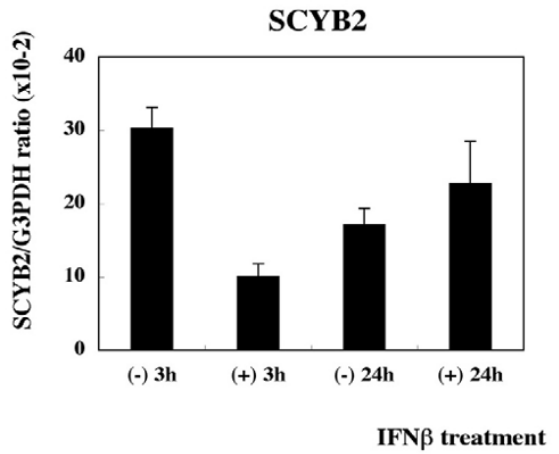

(e)

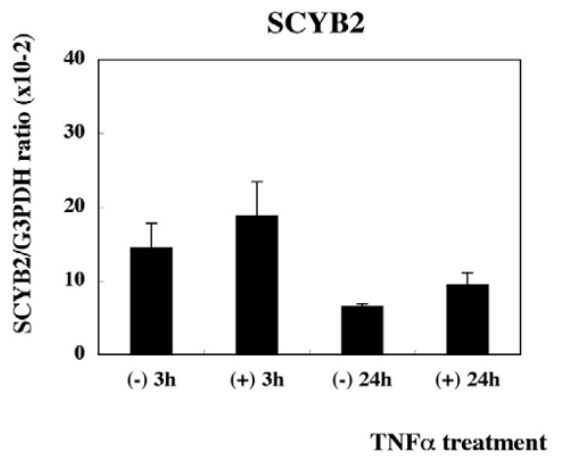

(c)

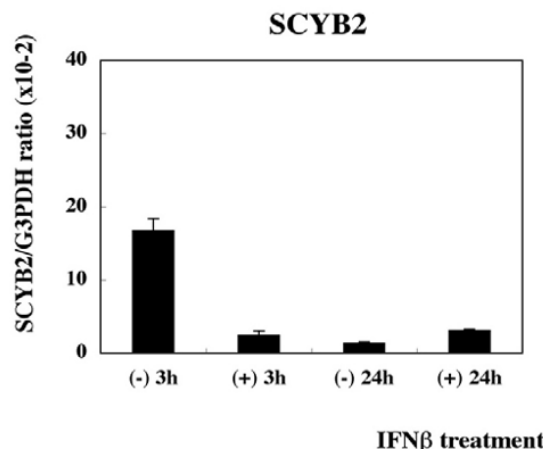

(f)

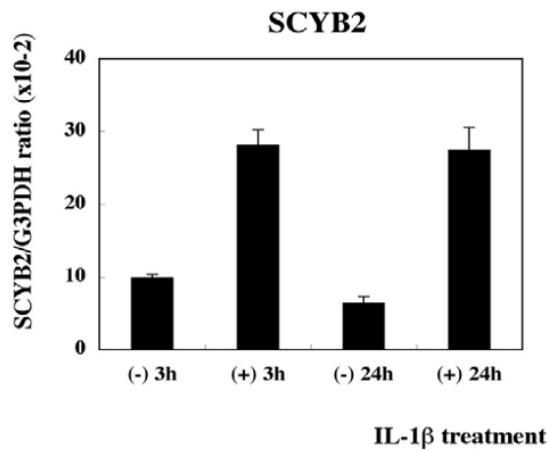

Figure 7

Real-time RT-PCR analysis of SCYB2 expression in PBMC. See the footnote of Figure I. The panels represent the expression of SCYB2 in (a) \#I, IFN $\beta$; (b) \#2, IFN $\beta$; (c) \#3, IFN $\beta$; (d) \#I, IFN $\gamma$; (e) \#I, TNF $\alpha$; and (f) \#I, IL-I $\beta$.

\section{Discussion}

IFNs are a family of cytokines that mediates antiviral, antiproliferative and immunoregulatory activities. Type I IFNs, IFN $\alpha$ and $\beta$, are produced principally by virusinfected host cells, whereas type II IFN, IFN $\gamma$, is produced by activated $\mathrm{T}$ cells and natural killer (NK) cells. Type I IFNs activate JAK protein tyrosine kinases associated with the cell surface receptors for IFNs, leading to formation of the complex of signal transducer and activator of transcription (STAT) molecules with the IFN regulatory factor (IRF) family of transcription factors. The STAT/IRF complex translocates into the nucleus, and binds to the DNA sequences termed the IFN-stimulated response element (ISRE) or the IRF-recognition element (IRE). This binding subsequently activates transcription of a wide variety of IFN-responsive genes (IRGs) as well as the genes of type I and type II IFNs, leading to the biological responses triggered by the IFNs [24]. Both type I and type II IFNs enhance the expression of class I and class II MHC molecules [25]. Among nine distinct IRFs, IRF7 and IRF3 play a central role in induction of type I IFN genes via the virus- activated MYD88-independent pathway or Toll-like receptor (TLR)7, 8 or 9-activated MYD88-dependent pathway [26], while IRF1 plays more active roles in induction of IFN $\gamma$-target genes essential for Th1-type immune response [25].

The present study by analyzing DNA microarray characterized a comprehensive list of immediate early IRGs in PBMC in vitro. Following a 3 to 24 hour-exposure to IFN $\beta$, upregulated genes greatly outnumbered downregulated genes. All top 20 upregulated genes represent known IRGs previously identified in various cell types. The upregulated IRGs of PBMC were classified into several functional categories. The list included not only conventional IFNresponse markers and components of IFN-signaling pathways, but also contained many proinflammatory chemokines and cytokines. This is surprising because IFN $\beta$ acts principally as an anti-Th1, anti-inflammatory cytokine $[6,7]$. By analyzing global gene expression profile, the present study for the first time showed that IFN $\beta$ induced a burst of gene expression of CXCR3 ligand chemokines 
(SCYB11, SCYB10 and SCYB9) and CCR2 ligand chemokines (SCYA8 and SCYA2), which was verified by quantitative real-time RT-PCR analysis. The chemokine genes actually have ISRE or IRE in the promoter regions, indicating direct targets of IFN $\beta[27,28]$.

CXCR3 is expressed predominantly on activated Th1 T cells, while CCR2 is expressed chiefly on monocytes [29]. The number of CXCR3 ${ }^{+} \mathrm{T}$ cells is increased in the blood of RRMS, and they accumulate in perivascular infiltrates in active MS lesions [30,31], while SCYB10 (IP-10) and SCYB9 (MIG) are detected in the cerebrospinal fluid (CSF) of RRMS at acute relapse and expressed in reactive astrocytes in active MS lesions [31,32]. SCYA2 (MCP1) and SCYA8 (MCP2) immunoreactivities are also identified in reactive astrocytes in active demyelinating lesions of MS $[33,34]$. These observations suggest that CXCR3, CCR2, and their ligand chemokines positively regulate active inflammation in MS. Although the precise cell types expressing CXCR3 ligand and CCR2 ligand chemokines in PBMC in response to IFN $\beta$ remain to be characterized, the chemokine burst plays a central role in rapid activation and systemic recruitment of Th1 T cells and monocytes immediately after initiation of IFN $\beta$ treatment. A recent study showed that IFN $\beta$ promotes trafficking of mouse leukocytes by regulating a specific set of chemokines [35]. However, concurrent upregulation of a set of CXCR3 and CCR2 ligand chemokines has not previously been reported in MS patients on a long-term IFN $\beta$ treatment $[16,17,20-22]$, suggesting that this phenomenon is an immediate early but transient event in vivo. IFN $\beta$ immediately reduced the expression of RGS14 (the most significantly downregulated gene at 3 hours; see Table 3 ), a member of the regulator of $G$ protein signaling (RGS) gene family that acts as a negative regulator of $G$ proteincoupled receptor (GPCR) signaling. Since all chemokine receptors are GPCR, IFN $\beta$-induced downregulation of RGS14 might facilitate chemokine responsiveness in the cells expressing RGS14 [36,37]. Much less is known about the mechanism for regulation of IFN $\beta$-repressed genes [38]. We identified IL-8 as one of IFN $\beta$-repressed genes in PBMC (Table 3). IFN $\beta$ inhibits the transcription of IL-8 gene, possibly by binding of NF- $\mathrm{kB}$ repressing factor (NRF) to a negative regulatory element of the IL-8 promoter [39]. Serum IL-8 levels and IL-8 secretion from PBMC are elevated in untreated MS, and then reduced following IFN $\beta$ therapy [40]. Downregulation of IL-8 expression in PBMC during IFN $\beta$ treatment provides a predictive indicator for the responders in RRMS [20].

IFN $\beta$ also promptly upregulated a variety of proinflammatory cytokines, such as IL-6, IL-15, osteopontin, TNF $\alpha$, and IFN $\gamma$ in PBMC (Table 4). IFN $\beta$ promotes production of TNF $\alpha$ and IFN $\gamma$ in unstimulated PBMC but decreases their levels in preactivated PBMC [41-43]. IFN $\beta$ increases the number of IFN $\gamma$-secreting cells in vivo at the early period of the treatment [44]. Most importantly, proinflammatory cytokines and chemokines induced by IFN $\beta$ have relevance to treatment-related early adverse effects. There exists a close relationship between flu-like symptoms and increased levels of IL-6 [45]. A single injection of IFN $\beta$ induces a transient burst of SCYB10 (IP-10) in the plasma of RRMS patients, which correlates with an incidence of flu-like symptoms [46]. IFN $\beta$ enhances the expression of CD80, SCYB10 (IP-10) and SCYA2 (MCP1) in situ at sites of injection, leading to chemotaxis of lymphocytes and monocytes in the lesions of skin reaction [47-49]. We found that IFN $\beta$ aberrantly regulated the levels of expression of several cytochrome P450 (CYP) enzymes (see Additional files 3,4,5,6). Type I IFN reduces the activity of CYP enzymes that metabolize various endogenous and exogenous substrates, probably leading to an increase in the potential for IFN-related hepatotoxicity [50].

Finally, the list of IRGs included various apoptosis regulators and HSP family members. ISRE-like sequences are identified in the regulatory element of CASP1, CASP4, CASP8, TNFRSF6 (FAS), TNFSF6 (FASL) and TNFSF10 (TRAIL), suggesting that IFN $\beta$ acts as a proapototic cytokine [51,52]. A recent study showed that early and sustained induction of TRAIL provides a marker for IFN $\beta$ treatment response in MS [53]. Furthermore, IFN $\beta$-inducible apoptosis regulators play an immunoregulatory role. TNFR1-associated via death domain (TRADD) inhibits IFN $\gamma$-induced STAT1 $\alpha$ activation [54]. Receptor-interacting serine-theronine kinase 1 (RIPK1) regulates TLR3independent viral double-stranded RNA-induced type I IFN production [55]. Because HSPs in general act as an anti-apoptotic defender, the induction of HSP gene expression might occur as a counterbalance against upregulation of proapoptotic regulators. Alternatively, IRGs could directly enhance HSP expression. IFN $\beta$-induced STAT1, by interacting with heat shock factor-1 (HSF1), activates the HSP70 and HSP90 $\beta$ gene promoters [56].

\section{Conclusion}

Microarray analysis showed that IFN $\beta$ immediately induces a burst of gene expression of proinflammatory chemokines and cytokines in vitro that have potential relevance to IFN $\beta$-related early adverse effects in MS patients in vivo.

\section{Abbreviations}

MS = multiple sclerosis; IFN $\beta=$ interferon-beta; IRGs = IFN $\beta$-responsive genes; PBMC = peripheral blood mononuclear cells; CNS = central nervous system; IFN $\gamma=$ interferon-gamma; Th $1=\mathrm{T}$ helper type $1 ; \mathrm{MHC}=$ major histocompatibility complex; RRMS = relapsing-remitting multiple sclerosis; ISG = IFN stimulated gene; TLR = Toll- 
like receptor; STAT $=$ signal transducer and activator of transcription; $\mathrm{IRF}=$ interferon regulatory factor; ISRE = interferon-stimulated response element; IRE $=$ interferon regulatory factor-recognition element; HSPs = heat shock proteins; $\mathrm{CSF}=$ cerebrospinal fluid; $\mathrm{GPCR}=\mathrm{G}$ proteincoupled receptor; $\mathrm{RGS}=$ regulator of $\mathrm{G}$ protein signaling.

\section{Competing interests}

The author(s) declare that they have no competing interests.

\section{Authors' contributions}

JS, YN and HT carried out DNA microarray and real-time RT-PCR analysis, and JS drafted the manuscript. TY participated in the design of the study and helped to draft the manuscript. All authors read and approved the final manuscript.

\section{Additional material}

\section{Additional File 1}

The gene list of cDNA microarray utilized in the present study. The complete gene list of cDNA microarray utilized in the present study is shown. It includes 1,258 well-annotated genes, selected from cytokines, growth factors and their receptors, apoptosis regulators, oncogenes, transcription factors, cell cycle regulators and housekeeping genes.

Click here for file

[http://www.biomedcentral.com/content/supplementary/14712377-6-18-S1.xls]

\section{Additional File 2}

Scatter plots of three distinct microarray experiments. The figure represents a scatter plot exhibiting the comparison between the fluorescence intensity (FI) of Cy5 signals in the longitudinal axis and FI of Cy3 signals in the horizontal axis. (a) the subject \#1 (a 46 year-old healthy man), (b) the subject \#2 (a 28 year-old healthy man), and (c) the subject \#4 (a 27 year-old woman with RRMS who was a dropout of IFN $\beta$ treatment due to induction of frequent severe relapses).

Click here for file

[http://www.biomedcentral.com/content/supplementary/14712377-6-18-S2.ppt]

\section{Additional File 3}

The complete list of upregulated genes in PBMC following exposure to IFN $\beta$ for 3 hours. Upregulated genes in PBMC of the subject \#1 (a 46 year-old healthy man) by a 3 hour-exposure to $50 \mathrm{ng} / \mathrm{ml} \mathrm{recombinant}$ human IFN $\beta$ are listed with Cy5/Cy3 signal intensity ratio, gene symbol, GenBank accession number, and gene name. In vivo IRG in T cells and non-T cells of RRMS patients reported previously (Ref. 16) are underlined.

Click here for file

[http://www.biomedcentral.com/content/supplementary/14712377-6-18-S3.xls]

\section{Additional File 4}

The complete list of downregulated genes in PBMC following exposure to IFN $\beta$ for 3 hours. Downregulated genes in PBMC of the subject \#1 (a 46 year-old healthy man) by a 3 hour-exposure to $50 \mathrm{ng} / \mathrm{ml} \mathrm{recombinant}$ human IFN $\beta$ are listed with Cy5/Cy3 signal intensity ratio, gene symbol, GenBank accession number, and gene name.

Click here for file

[http://www.biomedcentral.com/content/supplementary/1471-

2377-6-18-S4.xls]

\section{Additional File 5}

The complete list of upregulated genes in PBMC following exposure to IFN $\beta$ for 24 hours. Upregulated genes in PBMC of the subject \#1 (a 46 year-old healthy man) by a 24 hour-exposure to $50 \mathrm{ng} / \mathrm{ml} \mathrm{recombinant}$ human IFN $\beta$ are listed with $C y 5 / C y 3$ signal intensity ratio, gene symbol, GenBank accession number, and gene name. In vivo IRG in T cells and non-T cells of RRMS patients reported previously (Ref. 16) are underlined.

Click here for file

[http://www.biomedcentral.com/content/supplementary/14712377-6-18-S5.xls]

\section{Additional File 6}

The complete list of downregulated genes in PBMC following exposure to IFN $\beta$ for 24 hours. Downregulated genes in PBMC of the subject \#1 (a 46 year-old healthy man) by a 24 hour-exposure to $50 \mathrm{ng} / \mathrm{ml} \mathrm{recom-}$ binant human IFN $\beta$ are listed with C $\gamma 5 / C \gamma 3$ signal intensity ratio, gene symbol, GenBank accession number, and gene name.

Click here for file

[http://www.biomedcentral.com/content/supplementary/14712377-6-18-S6.xls]

\section{Additional File 7}

Top 20 upregulated genes in PBMC following exposure to IFN $\beta$ for 3 hours: two additional subjects. Upregulated genes in PBMC of the subject \#2 (a 28 year-old healthy man) and \#4 (a 27 year-old woman with RRMS who was a dropout of IFN $\beta$ treatment due to induction of frequent severe relapses) following a 3 hour-exposure to $50 \mathrm{ng} / \mathrm{ml}$ recombinant human IFN $\beta$ are listed with Cy5/Cy3 signal intensity ratio, gene symbol, and gene name. Both CXCR3 ligand (yellow) and CCR2 ligand (blue) chemokines are highlighted.

Click here for file

[http://www.biomedcentral.com/content/supplementary/14712377-6-18-S7.xls]

\section{Acknowledgements}

This work was supported by grants to J-IS from Research on Psychiatric and Neurological Diseases and Mental Health, the Ministry of Health, Labour and Welfare of Japan (HI7-020) and Research on Health Sciences Focusing on Drug Innovation, the Japan Health Sciences Foundation ( $\mathrm{KH} 2 \mathrm{I} \mathrm{IOI),} \mathrm{and}$ by the Grant-in-Aid for Scientific Research, the Ministry of Education, Culture, Sports, Science and Technology of Japan (B-18300II8). The authors would thank Dr. Jun Tsuyuzaki, Department of Neurology, Komoro Kosei Hospital, Nagano, Japan for introducing us the patients.

\section{References}

I. Sospedra M, Martin R: Immunology of multiple sclerosis. Annu Rev Immunol 2005, 23:683-747.

2. Panitch HS, Hirsch RL, Schindler J, Johnson KP: Treatment of multiple sclerosis with $\mathrm{g}$ amma interferon: Exacerbations associ- 
ated with activation of the immune function. Neurology 1987 , 37: 1097-II02

3. The IFNB Multiple Sclerosis Study Group: Interferon beta-Ib is effective in relapsing-remitting multiple sclerosis. I. Clinica results of a multicenter, randomized, double-blind, placebocontrolled trial. Neurology 1993, 43:655-66I.

4. Jacobs LD, Cookfair DL, Rudick RA, Herndon RM, Richert JR, Salazar AM, Fischer JS, Goodkin DE, Granger CV, Simon JH, Alam JJ, Bartoszak DM, Bourdette DN, Braiman J, Brownscheidle CM, Coats ME Cohan SL, Dougherty DS, Kinkel RP, Mass MK, Munschauer FE 3rd, Priore RL, Pullicino PM, Scherokman BJ, Whitham RH, The Multiple Sclerosis Collaborative Research Group (MSCRG): Intramuscular interferon beta- I a for disease progression in relapsing multiple sclerosis. Ann Neurol 1996, 39:285-294.

5. Jacobs LD, Beck RW, Simon JH, Kinkel RP, Brownscheidle CM, Murray TJ, Simonian NA, Slasor PJ, Sandrock AW: Intramuscular interferon beta-I a therapy initiated during a first demyelinating event in multiple sclerosis. CHAMPS Study Group. N Engl Med 2000, 343:898-904

6. McRae BL, Semnani RT, Hayes MP, van Seventer GA: Type I IFNs inhibit human dendritic cell IL-I 2 production and ThI cell development. J Immunol 1998, 60:4298-4304.

7. Kozovska ME, Hong J, Zang YC, Li S, Rivera VM, Killian JM, Zhang JZ. Interferon beta induces T-helper 2 immune deviation in MS. Neurology 1999, 53:1692-1697.

8. Stone LA, Frank JA, Albert PS, Bash C, Smith ME, Maloni H, McFarland HF: The effects of interferon- $\beta$ on blood-brain barrier disruptions demonstrated by contrast-enhanced magnetic resonance imaging in relapsing-remitting multiple sclerosis. Ann Neurol 1995, 37:611-619.

9. Satoh J, Paty DW, Kim SU: Differential effects of beta and gamma interferons on expression of major histocompatibility complex antigens and intercellular adhesion moleculein cultured fetal human astrocytes. Neurology 1995, 45:367-373.

10. Waubant E, Vukusic S, Gignoux L, Dubief FD, Achiti I, Blanc S, Renoux $C$, Confavreux C: Clinical characteristics of responders to interferon therapy for relapsing MS. Neurology 2003 , 6I:184-189.

II. Rudick RA, Lee JC, Simon J, Ransohoff RM, Fisher E: Defining interferon $\beta$ response status in multiple sclerosis patients. Ann Neurol 2004, 56:548-555.

12. Neilley LK, Goodin DS, Goodkin DE, Hauser SL: Side effect profile of interferon beta-Ib in MS: Results of an open label trial. Neurology 1996, 46:552-554

13. Bielekova B, Martin R: Development of biomarkers in multiple sclerosis. Brain 2004, I 27:|463-|478.

14. Steinman L, Zamvil S: Transcriptional analysis of targets in multiple sclerosis. Nature Rev Immunol 2003, 3:483-492.

15. Wandinger KP, Strüzebecher CS, Bielekova B, Detore G, Rosenwald A, Staudt LM, McFarland HF, Martin R: Complex immunomodulatory effects of interferon- $\beta$ in multiple sclerosis include the upregulation of $\mathbf{T}$ helper I-associated marker genes. Ann Neurol 200I, 50:349-357.

16. Koike F, Satoh J, Miyake S, Yamamoto T, Kawai M, Kikuchi S, Nomura K, Yokoyama K, Ota K, Kanda T, Fukazawa T, Yamamura T: Microarray analysis identifies interferon $\beta$-regulated genes in multiple sclerosis. J Neuroimmunol 2003, I39:109-I I8.

17. Weinstock-Guttman B, Badgett D, Patrick K, Hartrich L, Santos R Hall D, Baier M, Feichter J, Ramanathan M: Genomic effects of IFN- $\beta$ in multiple sclerosis patients. J Immunol 2003 | 7 |:2694-2702.

18. Satoh J, Nakanishi M, Koike F, Miyake S, Yamamoto T, Kawai M Kikuchi S, Nomura K, Yokoyama K, Ota K, Kanda T, Fukazawa T, Yamamura $\mathrm{T}$ : Microarray analysis identifies an aberrant expression of apoptosis and DNA damage-regulatory genes in multiple sclerosis. Neurobiol Dis 2005, I 8:537-550.

19. van Boxel-Dezaire AH, van Trigt-Hoff SC, Killestein J, Schrijver HM, van Houwelingen JC, Polman $\mathrm{CH}$, Nagelkerken L: Contrasting response to interferon $\beta$ - I b treatment in relapsing-remitting multiple sclerosis: does baseline interleukin- I 2p35 messenger RNA predict the efficacy of treatment? Ann Neurol 2000 48:313-322.

20. Stürzebecher $S$, Wandinger KP, Rosenwald $A$, Sathyamoorthy $M$ Tzou A, Mattar P, Frank JA, Staudt L, Martin R, McFarland HF: Expression profiling identifies responder and non-responder phenotypes to interferon- $\beta$ in multiple sclerosis. Brain 2003 , 126:1419-1429.

21. Satoh J, Nakanishi M, Koike F, Onoue H, Aranami T, Yamamoto T, Kawai M, Kikuchi S, Nomura K, Yokoyama K, Ota K, Saito T, Ohta M, Miyake S, Kanda T, Fukazawa $T$, Yamamura $T$ : $T$ cell gene expression profiling identifies distinct subgroups of Japanese multiple sclerosis patients. I Neuroimmunol 2006, I 74: I08- I I8.

22. Baranzini SE, Mousavi P, Rio J, Caillier SJ, Stillman A, Villoslada P, Wyatt MM, Comabella M, Greller LD, Somogyi R, Montalban X, Oksenberg JR: Transcription-based prediction of response to IFN $\beta$ using supervised computational methods. PLoS Biol 2005, 3:e2.

23. Interferon Stimulated Gene Database Arranged intoFunctional Categories [http://www.lerner.ccf.org/labs/williams/xchiphtml.cgi]

24. Theofilopoulos AN, Baccala R, Beutler B, Kono DH: Type I interferons $(\alpha / \beta)$ in immunity and autoimmunity. Annu Rev Immunol 2005, 23:307-335.

25. Taniguchi T, Ogasawara K, Takaoka A, Tanaka N: IRF family of transcription factors as regulators of host defense. Annu Rev Immunol 200I, 19:623-655.

26. Honda K, Yanai H, Negishi H, Asagiri M, Sato M, Mizutani T, Shimada $\mathrm{N}$, Ohba Y, Takaoka A, Yoshida N, Taniguchi T: IRF-7 is the master regulator of type-I interferon-dependent immune response. Nature 2005, 434:772-777.

27. Marx N, Mach F, Sauty A, Leung JH, Sarafi MN, Ransohoff RM, Libby $P$, Plutzky J, Luster AD: Peroxisome proliferators-activated receptor- $\gamma$ activators inhibit IFN- $\gamma$-induced expression of the T cell-active CXC chemokines IP-I0, Mig, and I-TAC in human endothelial cells. J Immunol 2000, I 64:6503-6508.

28. Kim OS, Park EJ, Joe E, Jou I: JAK-STAT signaling mediates gangliosides-induced inflammatory responses in brain microglial cells. J Biol Chem 2002, 277:40594-4060I.

29. Zlotnik A, Yoshie O: Chemokines: a new classification system and their role in immunity. Immunity 2000, I 2: I 2|- I27.

30. Balashov KE, Rottman JB, Weiner HL, Hancock WW: CCR5+ and CXCR3 ${ }^{+} \mathrm{T}$ cells are increased in multiple sclerosis and their ligands MIP-I $\alpha$ and IP-IO are expressed in demyelinating brain lesions. Proc Natl Acad Sci USA 1999, 96:6873-6878.

31. Sørensen T, Tani M, Jensen J, Pierce V, Lucchinetti C, Folcik VA, Qin S, Rottman J, Sellebjerg F, Strieter RM, Frederiksen JL, Ransohoff RM: Expression of specific chemokines and chemokine receptors in the central nervous system of multiple sclerosis patients. J Clin Invest 1999, 103:807-8I5.

32. Simpson JE, Newcombe J, Cuzner ML, Woodroofe MN: Expression of the interferon- $\gamma$-inducible chemokines IP-IO and Mig and their receptor, CXCR3, in multiple sclerosis lesions. Neuropathol Appl Neurobiol 2000, 26: I33-142.

33. McManus C, Berman JW, Brett FM, Staunton H, Farrell M, Brosnan CF: MCP-I, MCP-2 and MCP-3 expression in multiple sclerosis lesions: an immunohistochemical and in situ hybridization study. J Neuroimmunol 1998, 86:20-29.

34. Van Der Voorn P, Tekstra J, Beelen RH, Tensen CP, Van Der Valk P, De Groot CJ: Expression of MCP-I by reactive astrocytes in demyelinating multiple sclerosis lesions. Am J Pathol 1999, | 54:45-5 I.

35. Hokeness KL, Kuziel WA, Biron CA, Salazar-Mather TP: Monocyte chemoattractant protein-I and CCR2 interactions are required for IFN- $\alpha / \beta$-induced inflammatory responses and aniviral defense in liver. J Immunol 2005, I 74: I549-I556.

36. Giorelli M, Livrea P, Defazio G, lacovelli L, Capobianco L, Picascia A Sallese M, Martino D, Aniello MS, Trojano M, De Blasi A: Interferon beta-I a counteracts effects of activation on the expression of G-protein-coupled receptor kinases 2 and 3, $\beta$-arrestin-I, and regulators of G-protein signaling 2 and 16 in human mononuclear leukocytes. Cell Signal 2002, 14:673-678.

37. Reif K, Cyster JG: RGS molecule expression in murine B lymphocytes and ability to down-regulate chemotaxis to lymphoid chemokines. J Immunol 2000, I 64:4720-4729.

38. Der SD, Zhou A, Williams BRG, Silverman RH: Identification of genes differentially regulated by interferon $\alpha, \beta$, or $\gamma$ using oligonucleotide arrays. Proc Natl Acad Sci USA 1998 95: $15623-15628$

39. Nourbakhsh M, Kälble s, Dörrie A, Hauser H, Resch K, Kracht M: The NF- $\kappa$ B repressing factor is involved in basal repression and interleukin (IL)-I-induced activation of IL-8 transcrip- 
tion by binding to a conserved NF- $\kappa$ B-flanking sequence element. J Biol Chem 200I, I 76:450I-4508.

40. Lund BT, Ashikian N, Ta HQ, Chakryan Y, Manoukian K, Groshen S, Gilmore W, Cheema GS, Stohl W, Burnett ME, Ko D, Kachuck NJ, Weiner LP: Increased CXCL8 (IL-8) expression in multiple sclerosis. J Neuroimmunol 2004, I55:161-|7|.

41. Iarlori C, Reale M, De Luca G, Di lorio A, Feliciani C, Tulli A, Conti $P$, Gambi D, Lugaresi A: Interferon $\beta$-Ib modulates MCP-I expression and production in relapsing-remitting multiple sclerosis. J Neuroimmunol 2002, 123:170- I79.

42. Rothuizen LE, Buclin T, Spertini F, Trinchard I, Munafo A, Buchwalder PA Ythier A, Biollaz J: Influence of interferon $\beta$-la dose frequency on PBMC cytokine secretion and biological effect markers. J Neuroimmunol 1999, 99:|3|-|4|

43. Comabella M, Imitola J, Weiner HL, Khoury SJ: Interferon- $\beta$ treatment alters peripheral blood monocytes chemokine production in MS patients. J Neuroimmunol 2002, 1 26:205-2 I2.

44. Dayal AS, Jensen MA, Ledo A, Arnason BG: Interferon-gammasecreting cells in multiple sclerosis patients treated with interferon beta-Ib. Neurology 1995, 45:2173-2177.

45. Martínez-Cáceres EM, Río J, Barrau M, Durán I, Borrás C, Tintoré M, Montalban X: Amelioration of flulike symptoms at the onset of interferon $\beta$-I $b$ therapy in multiple sclerosis by low-dose oral steroids is related to a decrease in interleukin-6 induction. Ann Neurol 1998, 44:682-685.

46. Buttmann $M$, Merzyn $C$, Rieckmann P: Interferon- $\beta$ induces transient systemic IP- I /CXCLI 0 chemokine release in patients with multiple sclerosis. J Neuroimmunol 2004, I 56: 195-203.

47. Sarris AH, Esgleyes-Ribot T, Crow M, Broxmeyer HE, Karasavvas N, Pugh W Grossman D, Deisseroth A, Duvic M: Cytokine loops involving interferon- $\gamma$ and IP-I0, a cytokine chemotactic for CD4 ${ }^{+}$lymphocytes: an explanation for the epidermotropism of cutaneous T-cell lymphoma. Blood 1995, 86:65I-658.

48. Marckmann S, Wiesemann E, Hilse R, Trebst $C$, Stangel M, Windhagen $A$ : Interferon- $\beta$ up-regulates the expression of co-stimulatory molecules CD80, CD86 and CD40 on monocytes: significance for treatment of multiple sclerosis. Clin Exp Immunol 2004, I 38:499-506.

49. Buttmann M, Goebeler M, Toksoy A, Schmid S, Graf W, BerberichSiebelt F, Rieckmann P: Subcutaneous interferon- $\beta$ injections in patients with multiple sclerosis initiate inflammatory skin reactions by local chemokine induction. J Neuroimmunol 2005, 168: $175-82$

50. Islam M, Frye RF, Richards TJ, Sbeitan I, Donnelly SS, Glue P, Agarwala SS, Kirkwood JM: Differential effect of IFN $\alpha-2 b$ on the cytochrome P450 enzyme system: a potential basis of IFN toxicity and its modulation by other drugs. Clin Cancer Res 2002, 8:2480-2487.

5I. Chawla-Sarkar M, Lindner DJ, Liu YF, Williams BR, Sen GC, Silverman $\mathrm{RH}$, Borden EC: Apoptosis and interferons: role of interferonstimulated genes as mediators of apoptosis. Apoptosis 2003, 8:237-249.

52. Geiss GK, Carter VS, He Y, Kwieciszewski BK, Holzman T, Korth MJ, et al:: Gene expression profiling of the cellular transcriptional network regulated by alpha/beta interferon and its partial attenuation by the hepatitis $C$ virus nonstructural $5 \mathrm{~A}$ protein. J Virol 2003, 77:6367-6375.

53. Wandinger KP, Lünemann JD, Wengert $O$, Bellmann-Strobl J, Aktas O, Weber A, Grundstrom E, Ehrlich S, Wernecke KD, Volk HD, Zipp F: TNF-related apoptosis inducing ligand (TRAIL) as a potential response marker for interferon-beta treatment in multiple sclerosis. Lancet 2003, 36 I:2036-2043.

54. Wesemann DR, Qin H, Kokorina N, Benveniste EN: TRADD interacts with STATI- $\alpha$ and influences interferon- $\gamma$ signaling. Nature Immunol 2004, 5: 199-207.

55. Balachandran S, Thomas E, Barber GN: A FADD-dependent innate immune mechanism in mammalian cells. Nature 2004, 432:40I-405.

56. Stephanou A, Isenberg DA, Nakajima K, Latchman DS: Signal transducer and activator of transcription-I and heat shock factor$\mathrm{I}$ interact and activate the transcription of the Hsp-70 and Hsp-90 $\beta$ gene promoter. J Biol Chem 1999, 274:I723-I728.

\section{Pre-publication history}

The pre-publication history for this paper can be accessed here:

http://www.biomedcentral.com/1471-2377/6/18/prepub
Publish with Bio Med Central and every scientist can read your work free of charge

"BioMed Central will be the most significant development for disseminating the results of biomedical research in our lifetime. "

Sir Paul Nurse, Cancer Research UK

Your research papers will be:

- available free of charge to the entire biomedical community

- peer reviewed and published immediately upon acceptance

- cited in PubMed and archived on PubMed Central

- yours - you keep the copyright

Submit your manuscript here:

http://www.biomedcentral.com/info/publishing_adv.asp
BioMedcentral 